\title{
Phytopathology
}

\section{Ilarviruses of Prunus spp.: A Continued Concern for Fruit Trees}

\author{
V. Pallas, F. Aparicio, M. C. Herranz, K. Amari, M. A. Sanchez-Pina, A. Myrta, and J. A. Sanchez-Navarro
}

First, second, third, and seventh authors: Instituto de Biología Celular y Molecular de Plantas, Universidad Politécnica de Valencia-Consejo Superior de Investigaciones Científicas, Avda. de los Naranjos s/n. 46022 Valencia, Spain; fourth and fifth authors: Dpto. de Biología del Estrés y Patología Vegetal, CEBAS-CSIC, Campus Universitario de Espinardo, P.O. Box 164, 30010 Espinardo-Murcia, Spain; and sixth author: Certis Europe B.V. Via Josèmaria Escrivà de Balaguer 6, 21047 Saronno (VA), Italy.

Current address of K. Amari: Department of Plant Physiology, Botanical Institute of the University of Basel, Hebelstrasse 1, CH-4056 Basel, Switzerland.

Accepted for publication 17 July 2012.

\section{ABSTRACT}

Pallas, V., Aparicio, F., Herranz, M. C., Amari, K., Sanchez-Pina, M. A., Myrta, A., and Sanchez-Navarro, J. A. 2012. Ilarviruses of Prunus spp.: A continued concern for fruit trees. Phytopathology 102:1108- 1120.

Prunus spp. are affected by a large number of viruses, causing significant economic losses through either direct or indirect damage, which results in reduced yield and fruit quality. Among these viruses, members of the genus Ilarvirus (isometric labile ringspot viruses) occupy a significant position due to their distribution worldwide. Although symptoms caused by these types of viruses were reported early in the last century, their molecular characterization was not achieved until the 1990s, much later than for other agronomically relevant viruses. This was mainly due to the characteristic liability of virus particles in tissue extracts. In addition, ilarviruses, together with Alfalfa mosaic virus, are unique among plant viruses in that they require a few molecules of the coat protein in the inoculum in order to be infectious, a phenomenon known as genome activation. Another factor that has made the study of this group of viruses difficult is that infectious clones have been obtained only for the type member of the genus, Tobacco streak virus. Four ilarviruses, Prunus necrotic ringspot virus, Prune dwarf virus, Apple mosaic virus, and American plum line pattern virus, are pathogens of the main cultivated fruit trees. As stated in the 9th Report of the International Committee on Taxonomy of Viruses, virions of this genus are "unpromising subjects for the raising of good antisera." With the advent of molecular approaches for their detection and characterization, it has been possible to get a more precise view of their prevalence and genome organization. This review updates our knowledge on the incidence, genome organization and expression, genetic diversity, modes of transmission, and diagnosis, as well as control of this peculiar group of viruses affecting fruit trees.

Additional keywords: genome activation, genome expression, seed transmission.

Ilarviruses are a group of isometric and labile viruses that can infect herbaceous and woody hosts. Four ilarviruses, Apple mosaic virus (ApMV), American plum line pattern virus (APLPV), Prune dwarf virus (PDV), and Prunus necrotic ringspot virus (PNRSV), are pathogens of a large number of cultivated fruit trees. These four viruses, as the rest of the members of the genus Ilarvirus (family Bromoviridae), are characterized by a tripartite genome and quasi-isometric particles $(32,167)$. They all share common biological properties and infect a wide range of Prunus species and plant families other than the family Rosaceae

Corresponding author: V. Pallas; E-mail address: vpallas@ibmcp.upv.es

* The $\boldsymbol{e}$-Xtra logo stands for "electronic extra" and indicates that the online version contains one supplemental figure.

http://dx.doi.org/10.1094/PHYTO-02-12-0023-RVW

(C) 2012 The American Phytopathological Society
$(66,165)$. PNRSV was initially described in 1941 on peach $(40)$. The name "prune dwarf" was derived from the stunting and leaf malformation symptoms observed on Fellenberg prune $(P$. domestica) (159). The diseases induced by PNRSV and PDV in stone fruits were known commonly as "ringspot diseases." ApMV was first described in apple (31) and later on stone fruits in Bulgaria (19). Plum line pattern disease was first reported in Kentucky (United States) by Valleau (166) and subsequently APLPV was identified as the causal agent $(89,130,166)$.

Ilarviruses have been considered as latent pathogens when affecting fruit trees and, consequently, their economical incidence has been underestimated. PNRSV causes significant crop losses depending on the host. Previous reports have shown that PNRSV is responsible for yield losses of up to $15 \%$ in sweet cherry and of up to $100 \%$ in peach (165). PNRSV can reduce bud-take in nurseries (148), decrease growth of fruit (10 to 30\%) and fruit yield (20 to 60\%), delay fruit maturity, and increase susceptibility to winter injuries in orchards $(70,110,165)$. Yield losses caused by 
PDV may reach up to $50 \%$ in sour cherry, whereas it causes low bud-take in nurseries (40 to 50\% compared with healthy stocks) and slower growth of young trees $(33,120)$. PDV is probably the most damaging almond-infecting ilarvirus and causes chlorotic mottle, line pattern, and occasionally, stunted vegetation in the Mediterranean region (101). PDV and PNRSV act synergistically in mixed infections, causing peach stunt disease and often leading to a progressive decline, provoking the death of stone fruit trees (165). Little is known about the real economic impact of ApMV and APLPV on stone fruit production. However, it has been shown that ApMV infection may result in growth reduction and yield losses in other crop species (hazelnut), and that it may cause reduced apple bud-take in nurseries and losses of $46 \%$ in Golden Delicious cultivars $(18,37,48,120)$. Given the scenario in which ilarviruses are proven to be economically important, it is quite surprising that their molecular characterization lagged behind that of other plant viruses and was delayed until the beginning of the 1990s due essentially to their extreme lability. Determination of the complete sequence of ilarvirus genomes contributed to the emergence of molecular approaches aimed at the study and diagnosis of these viruses.

\section{INCIDENCE AND SYMPTOMATOLOGY}

Virus distribution and incidence. Among ilarviruses that infect stone fruits, PNRSV, ApMV, and PDV occur worldwide, whereas APLPV has a more restricted geographical distribution, being mostly reported from Europe and North America $(48,49$, 120). ApMV is frequently found in stone fruits in Europe, where it is known also as European plum line pattern virus but it is rarely found in the United States $(35,44,131)$. APLPV, to differentiate from ApMV, is called American plum line pattern virus. Previously, it was thought that APLPV was limited to the United States and Canada. However, recently it has been isolated from trees of different Prunus species in several Mediterranean countries (3,39,114,117). Among ilarviruses affecting stone fruits, PNRSV and PDV have been reported with the highest incidence in several countries. However, results of these studies, conducted by several authors, are not comparable to each other due to the different sampling methodology and detection techniques. A comprehensive general picture of ilarvirus incidence in stone fruits in a wide geographical area can be drawn from extended field studies carried out in the Mediterranean region during 1992 to 2007. These studies, coordinated by the Mediterranean Agronomic Institute of Bari (Italy), involved 14 countries of Southern and Eastern Europe, Middle East, and North Africa, representing areas with different germplasm. The results of enzyme-linked immunosorbent assay (ELISA) testing of approximately 24,000 trees (almond, apricot, plum, peach, and sweet and sour cherry) demonstrated a high incidence $(23.5 \%)$ of ilarvirus infection. Of those infected trees, mixed infections were recorded in $76.4 \%$ of the trees. The ilarvirus infection was distributed as follows: PNRSV (46.4\%), PDV (40.7\%), ApMV (3.3\%), and mixed infection, mostly PNRSV and PDV (9.6\%). Among the different stone fruit species, cherry was the most infected (45.6\%), followed by almond $(24.5 \%)$, peach $(24.4 \%)$, plum (15.2\%), and apricot (6.2\%). Prevailing single viruses in different species were PDV in cherry $(35.4 \%$ of the total tested or $71 \%$ of the infected trees) and PNRSV in peach (17\% of the total tested or $53.3 \%$ of the infected trees). ApMV was found at a low incidence in all analyzed species, whereas no tests were done for APLPV $(29,63,105,115,139)$. APLPV may, however, be widely distributed because line pattern diseases have been reported from most countries where stone fruits are grown (120), but tests for APLPV were never carried out (116).

Host range and symptomatology. Within ilarviruses, ApMV and PNRSV have a wider host range. PNRSV infects naturally all Prunus spp. including both cultivated and wild species but also hop and rose. ApMV, besides many Prunus spp., occurs naturally in hazelnut, hop, Malus spp., Rubus spp., Rosa spp., Betula spp., Chenomeles spp., and Aesculus spp. In comparison to PNRSV and ApMV, PDV and APLPV infect only Prunus spp. PDV occurs mainly in sweet and sour cherry but has also been reported in peach and APLPV in Japanese plum, peach, flowering cherry, and sweet cherry $(48,122)$.

In general, symptoms caused by ilarviruses are very similar and may be misleading during preliminary field diagnosis (Fig. 1).

\section{FIGURE 1}

A, Necrotic spots and shot holes caused by Prunus necrotic ringspot virus in sweet cherry.

B, Chlorotic rings and spots caused by Prune dwarf virus in sweet cherry. C, Yellow line pattern and mosaic caused Apple mosaic virus

in apricot. D, Yellow to creamy line pattern caused by American plum line pattern virus in Japanese plum.
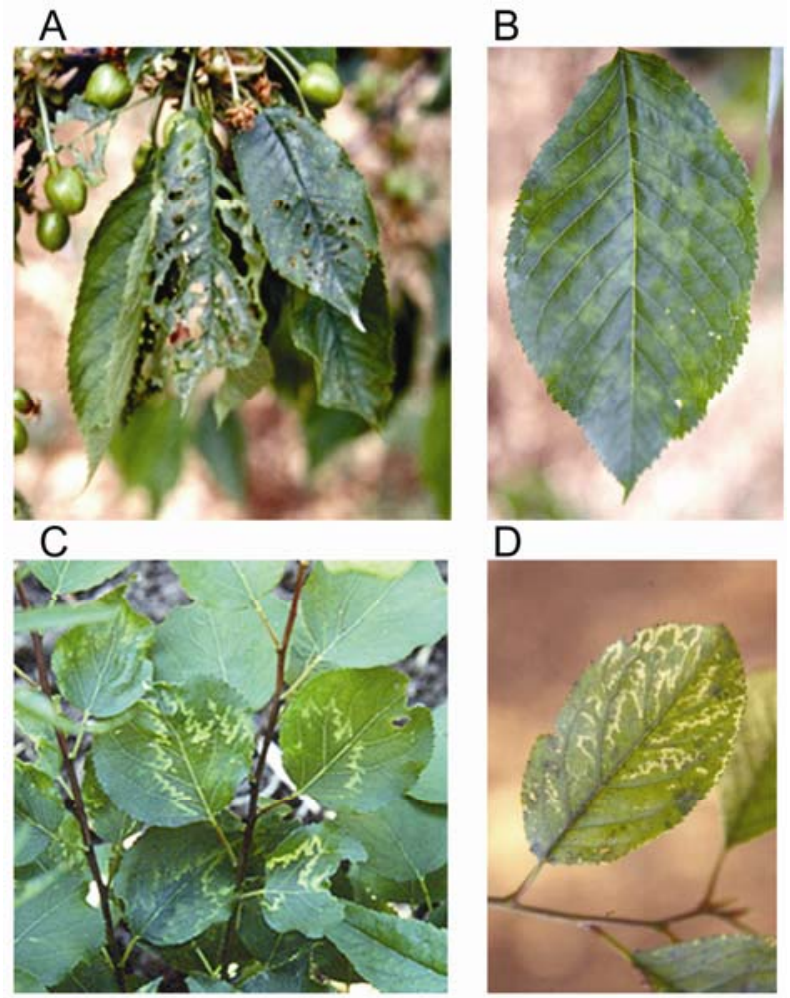
They may also vary in relation to virus isolate, host species or cultivar, climatic conditions, etc., or lead to latent infection. PNRSV may cause chlorotic to yellow line pattern mosaic and shot holes in leaves (Fig. 1A), rugose mosaic in cherries, bud death in trees and reduced bud-take after grafting, delay in fruit maturity (cherry), or discolored rings or spots in fruits (apricot). In general, symptoms of PNRSV appear in the first year after infection (acute or shock stage), and then commonly become symptomless, although some strains cause recurrent symptoms annually $(122,172)$. Infected sweet cherry trees produce smaller leaves, diffused chlorotic rings and/or spots (Fig. 1B), necrotic lesions or spots, which give a tattered appearance to the blade upon detachment $(85,165)$. PDV is associated particularly with sour cherry yellows disease (86) and stunting of plum and peach trees, usually in a mixed infection with PNRSV. PDV causes chlorotic mottle, line pattern, and occasionally, stunted vegetation in almond.

\begin{tabular}{|c|c|c|}
\hline \multicolumn{3}{|c|}{$\begin{array}{c}\text { TABLE } 1 \\
\text { Taxonomic structure of the family Bromoviridae } \\
\text { (type species in brackets) and description of species } \\
\text { belonging to the genus /larvirus }\end{array}$} \\
\hline Genus & Subgroup & Type species \\
\hline Alfamovirus & & (Alfalfa mosaic virus) \\
\hline Anulavirus & & (Pelargonium zonate spot virus) \\
\hline Bromovirus & & (Brome mosaic virus) \\
\hline Cucumovirus & & (Cucumber mosaic virus) \\
\hline Oleavirus & & (Olive latent virus 2) \\
\hline Ilarvirus & & (Tobacco streak virus) \\
\hline \multicolumn{3}{|c|}{ Subgroup 1} \\
\hline & & Parietaria mottle virus \\
\hline & & Tobacco streak virus \\
\hline \multicolumn{3}{|c|}{ Subgroup 2} \\
\hline & & Asparagus virus 2 \\
\hline & & Citrus leaf rugose virus \\
\hline & & Citrus variegation virus \\
\hline & & Hydrangea mosaic virus \\
\hline & & Lilac ring mottle virus \\
\hline & & Spinach latent virus \\
\hline & & Tulare apple mosaic virus \\
\hline \multicolumn{3}{|c|}{ Subgroup 3} \\
\hline & & Apple mosaic virus \\
\hline & & Blueberry shock virus \\
\hline & & Prunus necrotic ringspot virus \\
\hline \multicolumn{3}{|c|}{ Subgroup 4} \\
\hline & & Fragaria chiloensis latent virus \\
\hline & & Prune dwarf virus \\
\hline \multicolumn{3}{|c|}{ No relationships to other existing groups } \\
\hline & & American plum line pattern virus \\
\hline & & Humulus japonicus latent virus \\
\hline $\begin{array}{l}\text { a Currently acc } \\
\text { the ICTV }(32 \\
\text { described in }\end{array}$ & $\begin{array}{l}\text { pted groupin } \\
\text { Ilarviruses th } \\
\text { is review are }\end{array}$ & $\begin{array}{l}\text { of ilarviruses after the Ninth Report o } \\
\text { affect fruit trees and that have beer } \\
\text { bold. }\end{array}$ \\
\hline
\end{tabular}

ApMV and APLPV cause very similar clear-cut line pattern mosaic, yellow to creamy color, in all infected stone fruit species (Fig. 1C and D). ApMV is one of the main causes of mosaic symptoms in almond trees (95). It is considered to be one of the causes of the "yellow line pattern" on Prunus spp. (48). APLPV causes a sequence of pattern types, starting with chlorotic ring and oak-leaf type pattern and finally yellow vein banding. In the early summer, the yellow line pattern fades in to a creamy-white one. However, these symptoms may also be caused by ApMV or less frequently by PNRSV and PDV (48).

\section{GENOME STRUCTURE}

The genus Ilarvirus is one of the six genera included in the family Bromoviridae (Table 1). All members of this family have the same genomic organization consisting of a tripartite singlestranded messenger RNA genome encoding functionally similar translation products (Fig. 2). RNAs 1 and 2 encode the replicase subunits $\mathrm{P} 1$ and $\mathrm{P} 2$, respectively, whereas RNA3 is bicistronic encoding the movement protein (MP or P3) and the coat protein (CP). The latter is synthesized from a subgenomic RNA (sgRNA 4) derived from RNA3. All genomic RNAs contain cap structures at their $5^{\prime}$ ends and lack a poly(A) tail at their $3^{\prime}$ end.

The complete nucleotide sequences of the three genomic RNAs have been determined for most ilarviruses. In the case of ilarviruses infecting stone fruits the sequence of RNA1, RNA2, and RNA3 consist of 3,373, 2,979, and 2,053 nucleotides (nts) for APLPV; 3,476, 2,979, and 2,056 nts for ApMV; 3,374, 2,593, and 1,683 nts for PDV; and 3,332, 2,591, and 1,943 or 1,951 nts for PNRSV $(64,135,146,150,152-154)$.

RNA1. RNA1 of all members of genus Ilarvirus is monocistronic encoding the $\mathrm{P} 1$ replicase subunit which at its $\mathrm{N}$-terminal contains a methyltransferase domain (MT) (Fig. 2). This domain presents several motifs described in the alphavirus-like superfamily (140). Motifs I, Ia1, III, and IV are conserved in all four ilarviruses, whereas only PNRSV and PDV present motif IIa1 (CxxxxxxC) and ApMV lacks motif IIt1 (HxxSD). The P1 C-terminal part contains the NTPase/helicase-like domain (HEL) (61) with motifs I, II, III, IV, V, and VI strictly conserved. Mutation of a histidine $(\mathrm{H})$ residue to alanine $(\mathrm{A})$ placed in motif $\mathrm{V}$ in $\mathrm{P} 1$ of Brome mosaic virus (BMV) blocked RNA3 replication (171). At this position PNRSV and PDV contain an A, whereas APLPV and PDV $\mathrm{P} 1$ have a $\mathrm{H}$. The possible effects of these different residues in their replication mechanism have not yet been analyzed.

RNA2. RNA2 is monocistronic in APLPV, ApMV, PDV, PNRSV, Humulus japonicus latent virus (HJLV), and Lilac leaf chlorosis virus but bicistronic in all other members of the genus for which sequence information is available $(32,151)$. RNA2 of all ilarviruses encode the replicase subunit in their $5^{\prime}$ region (Fig. 2). P2 shows the highest homology at its C-terminal part. Moreover, several conserved features are present within the diverse motifs described in the polymerase domain (POL), such as the strictly conserved lysine $(\mathrm{K})$ residue in motif $\mathrm{I}$ or the GxxxTxxxNT and GDD signatures in motifs V and VI, respectively (91).

All other ilarviruses sequenced so far present a second open reading frame (ORF) that overlaps with the $3^{\prime}$ end of the $\mathrm{P} 2$ gene. This ORF encodes a putative $\mathrm{P} 2 \mathrm{~b}$ protein which could be functionally similar to the Cucumber mosaic virus (CMV) $2 \mathrm{~b}$ protein. CMV 2b is a suppressor of gene silencing and is required for long-distance transport of the virus (65). Although P2b protein of ilarviruses has never been detected in infected plants, a subgenomic RNA derived from RNA2 (sgRNA4A) has been found in plants infected with Spinach latent virus (SpLV) and Parietaria mottle virus $(51,79)$. A protein of approximately $22-\mathrm{kD}$ was translated in vitro from the SpLV sgRNA4A (79). Fragaria chiloensis latent virus, which is most closely related to PDV, has a 
bicistronic RNA2. However, the second ORF is not located on the same portion of the genome as the genes coding for $2 \mathrm{~b}$ proteins in other ilarviruses (160).

RNA3. As stated above, RNA3 is bicistronic and encodes the MP (or P3) and the CP which is synthesized from a subgenomic RNA (sgRNA4) derived from RNA3 (Fig. 2). The MP of ilarviruses belongs to the "30K superfamily" (113). MPs of this family are structurally characterized by the presence of a hydrophobic motif (HR) $(108,113)$. This motif is highly conserved in the family Bromoviridae $(41,146)$ and is preceded by a conserved RNA-binding domain (RBD), which is located between residues 56 to $85(11,54,75)$. Molecular variability studies among different APLPV isolates showed the presence of a similar putative basic RBD (74). On the other hand, the C-terminal part of PNRSV MP plays a critical role in the interaction with the cognate $\mathrm{CP}$ and contains a small domain necessary to target the MP to the plasmodesmata and for the functionality of the protein (15). Covariation analysis performed between the amino acid sequences of the MP and CP of PNRSV revealed that the MP residues V253, E256, D257, and T261 co-vary with the CP residues T52 and E141, suggesting a putative interaction across these regions (43). When all PNRSV isolates were analyzed, specific MP and CP covarying residues representatives of the PV32-I, PV96-II, and PE5III groups were characterized (54).

\section{GENOME EXPRESSION}

P1 and P2 polymerases. By analogy with other members in the family Bromoviridae, ilarvirus $\mathrm{P} 1$ and $\mathrm{P} 2$ proteins are considered as the subunits of the viral replicase complex (28). P1 is implicated in viral RNA recruitment and anchoring to the vacuolar membrane where replication complexes are assembled. Moreover, $\mathrm{P} 1$ provides methyltransferase and helicase activities, whereas P2 carries out RNA-dependent RNA polymerization. Subcellular localization studies using PNRSV P1 and P2 tagged with green fluorescent protein (GFP) showed that GFP:P1 accumulated in punctate structures probably associated with the vacuolar membrane, whereas P2:GFP remained as a soluble cytoplasmic proteins (M. C. Herranz and V. Pallas, unpublished data). Studies on the interchangeability of the noncoding sequences of AMV RNA3 with those of PNRSV led to the conclusion that the AMV replicase is able to recognize the 3' UTR of PNRSV and promotes minus-strand RNA synthesis but does not recognize the PNRSV promoter for genomic (plus-strand) RNA synthesis (13).

MP. The MP of ilarviruses, as with other plant viruses, is implicated in cell-to-cell movement. The best studied ilarvirus MP is that of PNRSV. PNRSV MP is involved in inter- and intracellular virus movement and contains an RBD with nine basic residues which confer a positive charge environment critical for RNA binding and viral cell-to-cell-movement $(75,77,145)$. Contiguous to this RBD is a hydrophobic region (HR) that facilitates its association to cellular membranes (102). Remarkably, a proline residue highly conserved in all known ilarviruses, located in the middle of the HR (Fig. 2), constrains the structural conformation of this region at the membrane interface, and its mutation impairs virus movement (102). In addition, the C-terminus region of PNRSV MP is required for the interaction with the cognate $\mathrm{CP}$ and is implicated in its targeting to the plasmodesmata (15). Moreover, as described for other members of the family Bromoviridae, PNRSV has the capacity to use either a CP-dependent or a CPindependent cell-to-cell transport through the specific interaction of the CP with the C-terminal region of its MP $(15,118,144$, $145,157)$. Recently, it has been shown that, in some instances, plant virus MPs, in addition to facilitating cell-to-cell movement, can also cause developmental and metabolic alterations (references 46 and 126 provide review). A recent study, using a yeastbased approach, showed that the PNRSV MP is able to specifically increase eIF $2 \alpha$ phosphorylation in a Tor1p-dependent manner, suggesting that MP activates Gen2p and Tor1p nutrientregulated pathways uncovering a previously uncharacterized function of the PNRSV MP (10).

The $\mathrm{CP}$ and the genome activation process. Ilarviruses and Alfalfa mosaic virus (AMV) require the binding of CP to the $3^{\prime}$ terminal untranslated region ( $3^{\prime}$ UTR) of the genomic RNAs in a phenomenon called genome activation to initiate infection. It is well documented that CPs of ilarviruses are interchangeable in this process $(8,147)$. The $\mathrm{N}$-terminal region of ilarviruses $\mathrm{CP}$ contains a high proportion of arginine (R) and/or lysine $(\mathrm{K})$ residues (146), which are responsible for its binding to the $3^{\prime}$ UTR of its own RNA (20). Experiments with mutant peptides and comparative analysis of the $\mathrm{CP}$ sequences of ilarviruses led Ansel-McKinney and co-workers (9) to propose an RNA-binding

\section{FIGURE 2}

Diagram showing the genome organization of Prunus necrotic ringspot virus. RNAs 1, 2, and 3 and subgenomic RNA 4 are presented as green and black boxes for open reading frame RNAs and untranslated regions, respectively. The cap structure at the $5^{\prime}$ end of the RNAs is indicated. Yellow boxes represent viral proteins $\mathrm{P} 1$ and $\mathrm{P} 2$, movement protein (MP), and coat protein (CP) (indicated at the right). Domains methyltransferase (MET), helicase (HEL), and RNA-dependent RNA polymerase (POL) in the replication proteins $\mathrm{P} 1$ and $\mathrm{P} 2$, RNA binding domain (RBD), and hydrophobic region (HR) in the MP and RBD and the dimerization region (DR) in the $\mathrm{CP}$ are indicated. Amino acid sequences of RBD, HR, and DR of the MP and CP are shown with numbers indicating residue positions from the initial methionine. Basic residues implicated in viral RNA binding are in red. The critical proline residue 97 in HR is underlined.

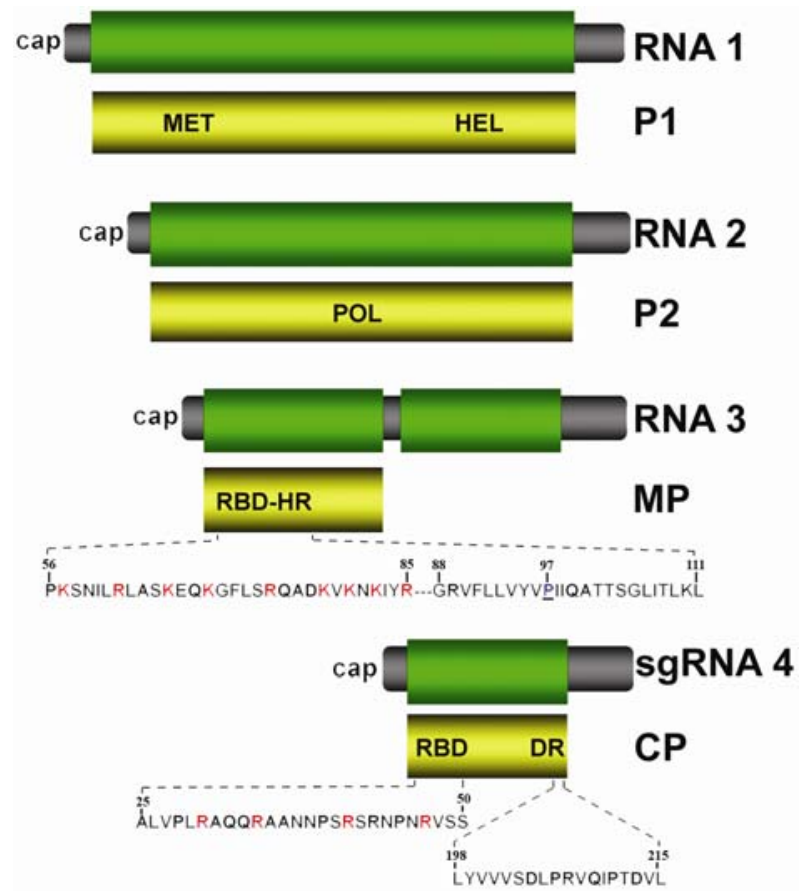


consensus sequence (Q/K/R-P/N-T-X-R-S-R/Q-Q/N/S-W/F/Y-A) in which a central $\mathrm{R}$ residue was shown to be essential for the binding to the RNA $(9,17,174)$. The PNRSV CP has the capacity to bind to the $3^{\prime}$ UTR of its RNA3 and $4(17,128)$ through an RNA-binding domain (RBD) rich in R residues located at the $\mathrm{N}$ terminal region between amino acid residues 25 to 50 of the protein. This domain is highly conserved in all the PNRSV isolates characterized so far $(11,54)$. In addition, the CP of ApMV and PNRSV present a zinc-finger motif, which has been postulated to confer an increased binding affinity and/or stability to the protein (17). A region located between residues 9 and 27 from the C-terminal end of the PNRSV CP plays a critical role in CP dimerization (DR in Fig. 2) (14).

The 3' UTRs of the RNAs of ilarviruses are predicted to be folded into a linear array of several stem-loops flanked by nonpaired sequences, in contrast to the tRNA-like structure present in most of the plant RNA viruses. In the case of PNRSV, its $3^{\prime}$ UTR folds in seven hairpins that represent at least three different $\mathrm{CP}$ binding sites (Fig. 3A) (17,128). In fact, as in the case of AMV and Tobacco streak virus (TSV) $(8,137)$, stem 1 is part of one of the binding sites (17). This stem is conserved in the four ilarviruses being considered in this review (Fig. 3B). The 3' UTR of PNRSV RNA3 can adopt an alternative tertiary conformation resembling a tRNA-like structure (TLS), through the formation of a pseudoknot (Fig. 3A). This pseudoknotted structure, when stabilized by the presence of $\mathrm{Mg}^{2+}$, inhibits the binding of the $\mathrm{CP}$ although would favor the binding of the replicase complex. This conformational switch between stem-loop and pseudoknot conformers, triggered by the $\mathrm{CP}$, has been proposed to represent a regulatory mechanism in the life cycle of members of the genus Ilarvirus (17), probably in a similar way as that proposed for AMV (124). Besides genome activation and virion formation, the $\mathrm{CP}$ of ilarviruses might be involved in the asymmetric plus-strand RNA accumulation, viral RNA translation, cell-to-cell movement, and the systemic spread of the virus, as has been shown for AMV (reviewed in 28).

\section{FIGURE 3}

The $3^{\prime}$ untranslated region ( $3^{\prime}$ UTR) of llarviruses infecting stone fruits. A, Schematic representation of the two mutually exclusive predicted conformations of the $3^{\prime}$ UTR of the Prunus necrotic ringspot virus (PNRSV) RNA 3. Stem-loops are denoted (1 to 7). Top structure represents the secondary linear conformation and bottom structure shows the putative proposed pseudoknot. Stem 1, which in PNRSV $3^{\prime}$ UTR was found to be part of one coat protein binding site and is implicated in stabilizing the pseudoknot, is filled in gray. $\mathbf{B}$,

Alignment of the $3^{\prime}$ UTR of Apple mosaic virus (ApMV), PNRSV, Prune dwarf virus (PDV), and American plum line pattern virus (APLPV). Nucleotides of stem-loop 1 are filled in gray.

\section{GENETIC DIVERSITY AND PHYLOGENETIC RELATIONSHIPS}

The members of the genus Ilarvirus were historically subdivided into seven subgroups according to their antigenic properties (167). A recent reevaluation of the serological relationships reduced this genus to six groups (53) and more recently to four (32) (Table 1). Phylogenetic analysis performed by using the MP and CP gene sequences (42) or partial sequences of the RdRp (99) grouped all ilarviruses plus AMV in five or six subgroups, respectively. Interestingly, based on the RNAs 1 and 2 sequence analyses, Boulila (30) divided the genus Ilarvirus in three subgroups with the four ilarviruses affecting fruit trees clustered in subgroup I.

PNRSV. At least $150 \mathrm{CP}$ and $72 \mathrm{MP}$ sequences have been described for different PNRSV isolates originating from the United States, South America, Europe, and the Mediterranean area (deposited in GenBank). Analysis of the patterns of nonsynonymous $\left(\mathrm{d}_{\mathrm{N}}\right)$ and synonymous $\left(\mathrm{d}_{\mathrm{S}}\right)$ substitution in the $\mathrm{CP}$ gene of 36 viruses with different modes of transmission showed that PNRSV CP had the highest $d_{N} / d_{S}$ ratio revealing significant evidence for positive selection of the corresponding gene (38). Earlier phylogenetic analysis suggested the clustering of the PNRSV variants into three groups named after representative PNRSV isolates PV32, PV96, and PE5 $(11,12)$ (Fig. 4A). The posterior phylogenetic analysis performed by Vaskova et al. (168) confirmed the clustering of PNRSV variants into three subgroups with an alternative nomenclature (I, II, and III for PV32, PV96, and PE5, respectively). An additional phylogroup named $\mathrm{CH} 30$ was proposed by Glasa et al. (60). Further phylogenetic analysis performed with additional isolates from South America confirmed the existence of the three phylogroups irrespective of the protein sequence (MP or CP) employed for the analysis (41,54). In addition, the alignment of the MP and $\mathrm{CP}$ sequences revealed the existence of residues representatives of the three phylogroups (54). Regarding the MP sequence, D/I 257 is specific for the
A

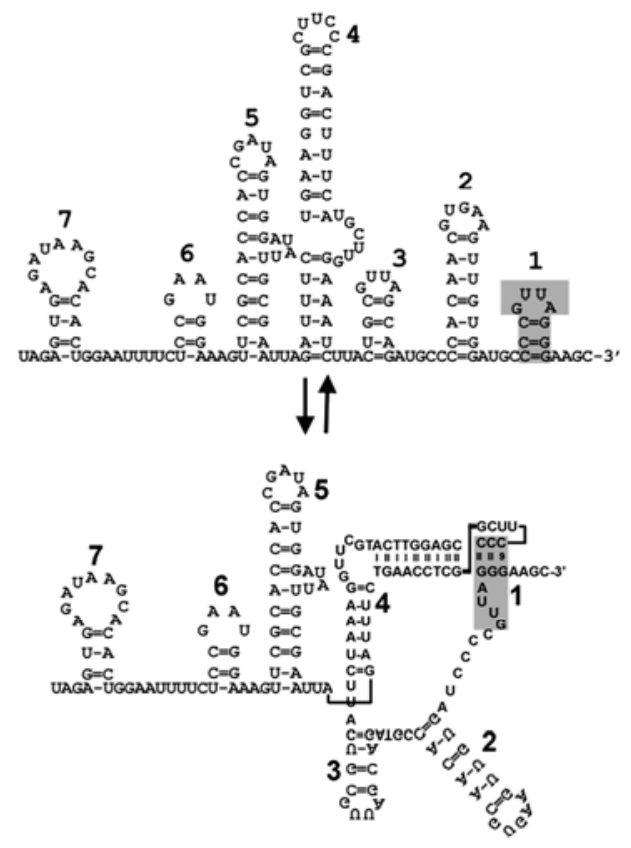

B

ApMV

PNRSV

PDV

APLPV
CAATTTCTGTGAAAGAAATTGATGCCCCGATTAGGA-GGC-3' CCACAAC-GTG-AAGTTGTGGATGCCCCGTTA-GGGAAGC- $3^{\prime}$ CCTCACC---GTAAGGTGAGGATGCCCCTTTAAGGGATGC-3' TTTCTTT--CGAAAAAATGAAATGACCCTTAG-GGG--CC-3' 


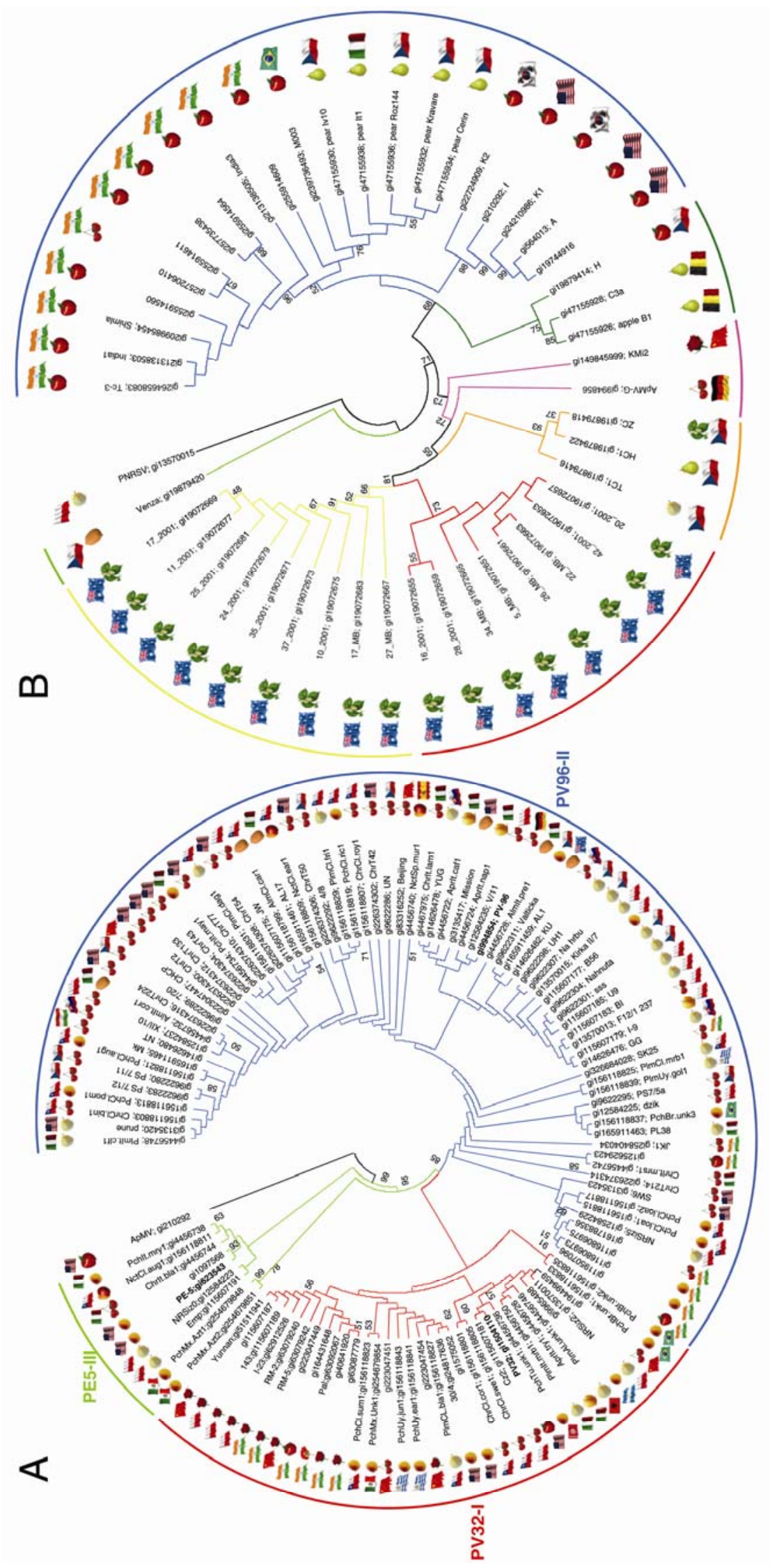

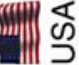

艘意

틀

H嘀

这

章

도월

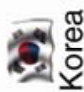

즐

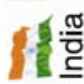

H

彭

重

产产

耧旁言

ำ

등

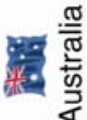

此宒

四兴

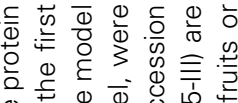

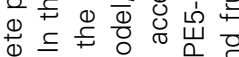

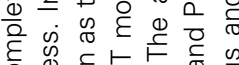

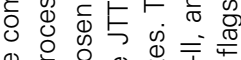

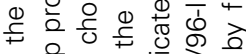

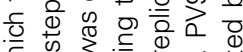

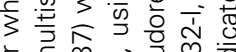

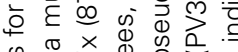

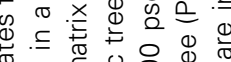

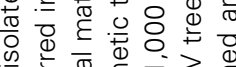

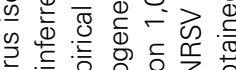

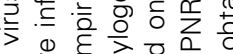

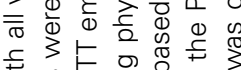

a.

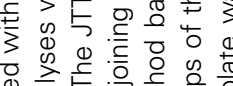

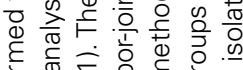

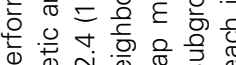

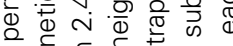

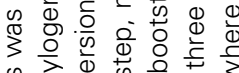

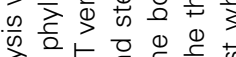

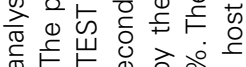

T)

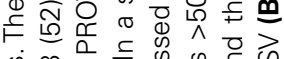

它

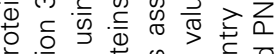

亭

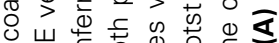

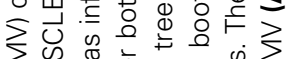

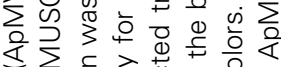

क

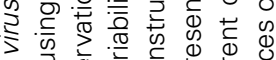

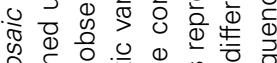

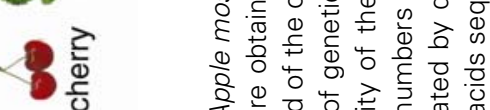

$\rightarrow \frac{\mathrm{c}}{\mathrm{c}}$

(1) $\frac{0}{\frac{0}{2}}$

ํํำ

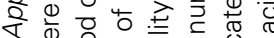

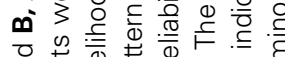

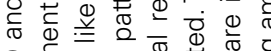

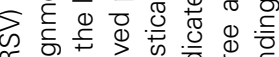

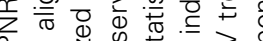

w. 을

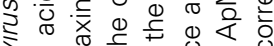

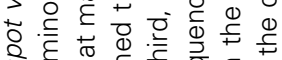

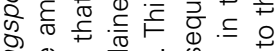

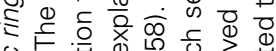

布

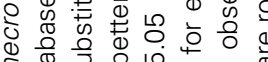

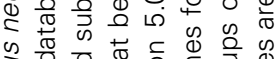

为

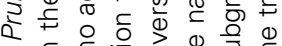

过

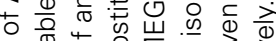

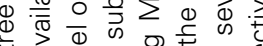

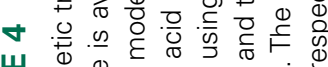

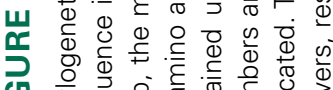

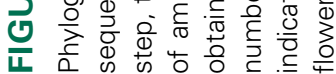


PV96-II group (with the exception of the SW6 isolate from cherry, AF013287), while amino acids V257 and L261 are representative of the PV32-I group. The PE5-III group contains the largest number of specific residues with N32, S/H41, I250, L253, E/G257, S/I264, T266, V274, R/G281, and T282. Concerning the CP sequence, only the PV32-I and PE5-III groups contain specific residues in their $\mathrm{CP}$ sequences. Isolates belonging to the PV32-I are characterized by the presence of two extra residues (N/S42 and R43) and the amino acid Y81. Only isolates CH38 (AF034991) and CH57 (AF034993) or PchBr.unk1 (gi156118833) and PchBr.unk2 (gi156118835) do not contain the additional amino acids or the Y81 residue, respectively. The presence of the two extra amino acids (six nucleotide insertions) has been associated to a stem-loop structure allowing intramolecular rearrangement due to discontinuous transcription by the RNA polymerase (11). Residues K59, N121, R139, N142, and I181 are specific of the phylogroup PE5-III. In spite of the presence of the three phylogroups, the clustering did not correlate with specificity of host species, symptomatology, or geographic origin, although most of the American isolates are grouped in the PV96-II group, confirming earlier reports $(11,12,69,123,152,156,168)$. Nonetheless, the majority of isolates from phylogroups PV69-II and PV32-I tend to exhibit latent/mild or chlorotic/necrotic symptoms, respectively $(11,12)$. Furthermore, the overall expected distribution for the members of each phylogroup was approximately 58.0\% PV96-II, 33.3\% PV32-I, and 8.7\% PE5-III irrespective of the geographic area and host species sampled (54). A recent analysis of the genetic diversity of PNRSV isolates within a cherry orchard in New York revealed that these isolates clustered in the predominant group PV96 (123). On the other hand, sequence analysis of the RNA3 of seven PNRSV isolates from sweet cherry trees collected in the United States revealed single nucleotide and amino acid changes in the MP and/or CP sequences which correlate with serological relationship and pathotypes $(71,72)$. Remarkably, an adaptive covariation phenomenon between the $\mathrm{CP}$ and MP sequences of PNRSV has been described by Codoñer et al. (43) that could explain certain protein-protein and RNA-protein interactions observed later by Aparicio et al. (15).

ApMV. The molecular characterization of ApMV isolates has been addressed basically in the $\mathrm{CP}$ gene for a significant number of isolates from different geographic origins (Australia, Belgium, Brazil, China, Czech Republic, Germany, India, Italy, Korea, Poland, Spain, and the United States) and hosts (almond, apple, cherry, hop, pear, plum, and rose). Earlier studies on phylogenetic characterization of $\mathrm{CP}$ genes of ApMV isolates from different countries and hosts grouped all variants into three subgroups (I, II, and III) originating from apple, hop/pear, and almond, respectively, although the branch separations were not supported with high statistical values (96). Furthermore, Petrzik and Lenz (133) reported that 4 out of 11 isolates had nucleotide insertions of various lengths ( 6 to $15 \mathrm{nts}$ ) after the nucleotide position 141 in the $\mathrm{CP}$ gene. This length variation of the $\mathrm{CP}$ gene clustered all available ApMV isolates into two groups that were not correlated with either the host or geographic origin. Recent phylogenetic analysis using additional CP and MP gene variants from India grouped the 25 isolates into five subgroups (named I to V) (94). Except for the Indian isolates that clustered mainly into subgroup I (with the exception of one isolate that was in subgroup II), the clustering of the rest of ApMV variants was not correlated with the geographic or host origins. ApMV isolates carrying nucleotide insertions after position 141 in $\mathrm{CP}$ were all grouped into the subgroups III, IV, and V. Recently, the sequence information of new ApMV isolates, mainly from Australia, has modified the phylogenetic tree, in which the bootstrap analysis supported the presence of seven groups (Fig. 4B).

PDV. Many sequences corresponding to the PDV CP gene have been characterized from different geographic origins (Argentina,
Brazil, Canada, Germany, Hungary, Israel, Moldova, Poland, Portugal, Russia, the United States, and Turkey) and hosts (almond, apple, apricot, cherry, peach, plum, sour cherry, sweet cherry, and wild cherry). Previous phylogenetic analysis showed a lack of correlation between amino acids substitutions and host and/or geographic origin $(56,169)$. However, posterior phylogenetic analysis using additional PDV CP gene nucleotide sequences isolated from different stone fruit tree species in Turkey indicated the existence of four groups related to the host. These groups are (i) cherry I, containing only cherry variants; (ii) cherry II, consisting of one apricot variant and cherry variants; (iii) mixed, including variants from cherry, peach, plum, and one almond tree; and (iv) almond, consisting only of almond variants (161). When the phylogenetic analysis was performed using the $\mathrm{CP}$ amino acid sequences of all PDV isolates available in the database, the bootstrap analysis supported the presence of only two groups (Supplemental Figure 1). Remarkably, Fonseca et al. (56) found that PDV CP sequences from almond isolates showed a much higher variability that those originating from other Prunus spp. (peach, cherry, and plum) suggesting a more intense purifying selection for the latter hosts.

APLPV. For APLPV there are two complete RNA3 sequences of American and Mediterranean isolates in GenBank as well as the complete sequence of the $\mathrm{CP}$ and MP genes of 10 isolates. The phylogenetic analysis using the $\mathrm{CP}$ and $\mathrm{MP}$ genes grouped the different isolates with very low bootstrap values indicating a lack of geographically associated variation between American and Mediterranean isolates (74). In a previous taxonomic study of viruses of all genera of the family Bromoviridae, Codoñer and Elena (42) found that APLPV was related to PDV, PNRSV, and ApMV. In our analysis, we observed that APLPV was always separated from the rest of ilarviruses as the unique members of subgroup 5, independently of the RNA sequence used for the phylogenetic analysis (41).

\section{DIAGNOSIS}

All ilarviruses affecting fruit trees can be detected by grafting onto woody indicator plants such as GF305 peach seedlings and sap inoculation of suitable herbaceous indicator plants (review provided in literature citations 48 and 83). Although ilarviruses are weakly immunogenic, serological procedures allowed for routine detection analysis, first based on agar immunodiffusion with or without electrophoresis and later on with the ELISA format that revolutionized the plant virus diagnosis (review provided in literature citation 34). Monoclonal antibodies have been produced for ApMV (129), PNRSV (68,112), and PDV (27). A recombinant PDV CP was obtained for the production of a PDV antiserum that avoided the purification procedure of this labile virus (2). APLPV is not serologically related to any of the other ilarviruses that affect woody hosts. Its detection by ELISA was described by Fulton (59). ELISA methodologies have been used to determine the incidence of these viruses, however, confusing results have sometimes been obtained. For instance, erratic ELISA results have been reported for shoot-leaf samples collected in early May when day temperatures exceeded $38^{\circ} \mathrm{C}$ over a 12-day period (164). In addition, Scott et al. (149) described that PNRSV was detectable by ELISA in peach tissue only until stem elongation ceases.

With the advent of the molecular characterization of these viruses in the 1990s, molecular hybridization using radiolabeled probes allowed the discrimination between healthy and PNRSVinfected material throughout the growing season (149). This methodology was also suitable for detecting isolates that represent the various PNRSV serotypes reacting poorly in ELISA (45). Nevertheless, the use of radiolabeling rendered this approach unsuitable for routine diagnosis. Nonisotopic RNA probes (127) were developed and used to monitor PNRSV infection after in vitro micrografting $(78)$ and to detect this virus $(127,141,143)$ and 
APLPV $(3,4)$ in field conditions. A very interesting variant of this methodology was the "tissue-printing" approach (103) that avoids sample extraction and only requires the direct transfer of the plant material (stem, cutting, leaf, and fruit) to a nylon or nitrocellulose membrane. This strategy has been used to track PNRSV, ApMV, and PDV in stone fruit trees throughout the year (106).

Several variations of the PCR technique have been applied to the detection of the four ilarviruses of fruit trees at very low concentrations (see literature citation 67 and references therein for review) and differentiation among isolates (73) through a transcript conformation polymorphism methodology (138). As a step towards the development of more rapid methods of detection, different approaches have been developed for the simultaneous detection of multiple plant viruses $(55,81)$. In the case of the ilarviruses affecting fruit trees, mixtures of several nonisotopic probes were used in molecular hybridization, for instance for the detection of PNRSV, PDV, and ApMV (141). Detection of two ilarviruses or one ilarvirus together with other important stone fruit virus, e.g., PNRSV and PPV (90) or PDV and PPV (173), in a single multiplex RT-PCR with the same sensitivity as that observed during simplex RT-PCR analyses has been reported. Additionally, a PCR-ELISA procedure has been described for the simultaneous detection of ApMV and PNRSV (36), but in this case, an extra probe-capture step was required to differentiate between the two viruses. PNRSV, PDV, and ApMV were simultaneously detected in a single assay by RT-PCR (141). Multiplex RT-PCR methods were developed to detect four apple viruses (109) and eight stone fruit viruses, including the four ilarviruses described in this review, in a single assay (142). A generic ramped-annealing nested RT-PCR was developed by Maliogka et al. (99) that allowed the simultaneous detection and fast characterization of ilarviruses and their demarcation based on the phylogeny of RNA2-encoded RNA-dependent RNA polymerase (RdRp). More recently, Massart et al. (104) carried out an interlaboratory evaluation of a duplex RT-PCR method for the simultaneous detection of PDV and PNRSV in which a level of sensitivity of $98.3 \%$ for PDV and $90.4 \%$ for PNRSV was achieved. PNRV, PDV, and Plum pox virus (PPV) were simultaneously detected by one-step multiplex RT-PCR with similar detection limits when compared with simplex RT-PCRs (82). Finally, a PCR assay was developed for the universal detection of ilarviruses using primers designed in the RdRp on RNA2 (162).

The attractive concept of "polyprobes" as a way to simultaneously detect different viruses was developed for the ilarviruses affecting stone fruits (76, see literature citation 125 for a review). In this first work partial nucleic acid sequences of PNRSV, PDV, ApMV, APLPV, PPV, and ACLSV were cloned in tandem allowing the synthesis of a unique riboprobe. More recently, Peiró et al. (132) developed a polyprobe able to detect eight different viruses plus two viroids affecting fruit trees. The results obtained with the poly 10 riboprobe clearly showed that viruses and viroids can be simultaneously detected in a single assay, with the same detection limit and specificity as with the single riboprobes.

In recent years, DNA microarray technology has enormously extended the power of nucleic acid hybridization since its ability to handle a large number of samples can potentially detect a range of viruses using a single test (21). Although its application to plant virus diagnosis is still rare, ilarviruses have been included in some of these arrays. Lenz et al. (97) developed an oligonucleotide microarray for the detection of PNRSV, PDV, and ApMV and concluded that the intrinsic sensitivity limit of the microarray and the nature of the viruses investigated did not enable the direct detection of viral cDNAs needing an amplification approach. Zhang et al. (175) designed an oligonucleotide microarray with a minimal number of probes for the detection and identification of 13 genera of plant viruses in which PNRSV was included. Finally, Nicolaisen (121) constructed a microarray with 150 probes poten- tially capable of detecting 52 viruses from a broad range of genera. Although the type member of the genus Ilarvirus was represented in this study, none of the ilarviruses affecting fruit trees was included.

\section{SEED AND POLLEN TRANSMISSION}

Seed and pollen transmission are common mechanisms of spread for approximately $20 \%$ of plant viruses and this assures their spread from generation to generation $(80,111)$. The introduction of a poorly seed-transmitted virus into a new area can be catastrophic if an efficient virus vector is available. Seed transmission may occur directly through the embryo infection from the mother plant as in Pea seed borne mosaic virus or indirectly via pollen or ovule during fertilization, as for example in Pea early browning virus (107). Within the family Bromoviridae at least one member of the different genera is transmitted by seed (80). Transmission by seed and pollen has been reported for PNRSV and PDV $(5,6,16,80,111)$. Interestingly, the mediation of thrips or other flower-visiting arthropods has been reported to be required for plant-to-plant transmission $(62,84,111)$. Although there was evidence for the presence of APLPV in seed coats of seeds collected from APLPV-infected cherry and plum fruits (A. Myrta, unpublished data) whether it leads to seed transmission has not been demonstrated yet.

Silva and coworkers (155) elegantly demonstrated the presence of PDV in infected almond tissue by in situ RT-PCR. In addition to the leaves, PDV RNAs were detected in flower buds, especially in the generative and vegetative cells of pollen grains. The beststudied ilarvirus in terms of transmission is PNRSV. The virus invades early pollen grains, infecting the megaspore and generative cell of the bicellular pollen grain in nectarine (16) and apricot trees (5; Fig. 5). Furthermore, it was shown that PNRSV drastically reduces pollen germination and delay pollen tube growth. Concerning seed transmission, PNRSV infects all seed parts including the embryo at early developmental stages (6); thus, the embryo infection could occur through infected pollen/ovule or both. Germination of seeds collected from PNRSV-infected apricot trees showed that this virus was seed transmitted in $10 \%$ of infected seeds. Some of these seedlings showed severe dwarfing (6). Furthermore, cross pollination with infected pollen to healthy plants showed that PNRSV not only was able to infect seeds but also fruits, which indicated that PNRSV is probably transmitted to the pollinated healthy tree or at least to the fruits. Transmission to the pollinated healthy plant is not a common feature of all seed- and pollen-transmitted viruses, since many of them are not able to cross the border between the gametophytic and the vegetative tissue. Seed transmission could be regulated by some host factors and is also dependent on the virus isolate. Thus, the same virus can be transmitted with different rates in different hosts $(84,111)$. In addition, seed transmission can be different among the different varieties of the same host. For example, seed transmission rate of PNRSV in cherry is $88.8 \%$ (170) and $76.9 \%$ depending on the variety (92). Once the virus infects the seed, it should be able to persist and resist the physiological changes taking place during seed maturation and storage. Some seed-transmitted viruses are quickly eliminated during this process while others persist for many years. Fulton (58) showed that PNRSV was seedtransmitted in Prunus pennsylvanica at a rate between 60 and $70 \%$ after storage at $2{ }^{\circ} \mathrm{C}$ during 4 years, and that this percentage dropped to less than $5 \%$ after 6 years, while seed viability increased. In the case of AMV, virus inactivation in alfalfa seeds was not significantly different after storage during 5 years at $-18^{\circ} \mathrm{C}$ or room temperature (57). Experiments conducted with PNRSVinfected almond seed showed that the percentage of infected seeds dropped by $50 \%$ between seed maturation and stratification during 2 months at $4{ }^{\circ} \mathrm{C}(23)$. The virus inactivation process during 
seed maturation and storage is not yet clear. In the case of PNRSV, our studies have demonstrated that an oxidative stress accompanied by an imbalance in the antioxidant system in infected apricot seeds, similar to the hypersensitive response in some virushost interactions takes place (7). This defense mechanism would eliminate PNRSV from the seed during seed formation and/or the storage or even during germination. This mechanism could contribute to the decrease in seed germination and the low transmission rates of PNRSV by seed in apricot trees in particular, and other seed-transmitted viruses in general (7). The host factors that control virus seed transmission are not yet known. Recent studies of Soybean mosaic virus (SMV) in soybean-associated seed transmission and seed coat mottling of isolate SMV 413 with a chromosomal region with homology to Arabidopsis thaliana genes $D C L 3$ and RDR6, encoding enzymes involved in RNA-mediated transcriptional and posttranscriptional gene silencing (50).

\section{CONTROL}

The most important method for controlling the diseases caused by ilarviruses affecting fruit trees is the use of virus-tested certified plants in replant orchards or new orchards. In diseased orchards, effective management requires prompt removal and destruction of diseased plants, replacements for trees derived from virus-tested, clean certified stocks, and scouting for reinfection to limit disease expansion. Nurseries producing basic propagation material need to be separated from commercial orchards by an appropriate distance to prevent or limit contaminating pollen flow. Thermotherapy ( 24 to 32 days at $38^{\circ} \mathrm{C}$ ) and/or apical meristem culture have been used to eliminate ApMV $(22,119)$, PDV (49), and PNRSV $(26,88,100)$. In most cases a combination of both methods improves the efficiency of virus elimination (93). Conservation of propagation material done in a proper way in screen houses and isolated mother fields from commercial orchards by appropriate distances prevent or limit contaminating of pollen flow. The compulsory sanitary controls during the certification schemes should avoid any possibility of risk of reinfection during the production of healthy propagated material.

As PNRSV and PDV are pollen transmitted, these viruses can be transmitted in the field in distance from infected to healthy trees of the same species. Uyemoto et al. (163) provided statistical evidence that the existence of the same cultivar(s) in an orchard favored earlier virus infections, especially by PDV, than when different cultivars were present. Thus, these authors recom-

\footnotetext{
FIGURE 5

Distribution of Prunus necrotic ringspot virus (PNRSV) RNA in apricot reproductive organs by in situ hybridization (ISH), as shown by the blue color. A, Cross section of a mature infected anther. B, PNRSV RNAs accumulate in the aperture of mature infected pollen grains. C, Cross section of infected ovule at early developmental stage showing viral RNA in the nucellus $(\mathrm{Nu})$ surrounding the virus-free embryo sac (ES). D, High magnification of the nucellus region surrounding the embryo sac showing viral RNA in the nucleus and embryo

sac. $\mathbf{E}$, Early infection of the embryo (E). $\mathbf{F}$,

Negative control of the ISH conducted on healthy embryo from uninfected apricot tree.

$\mathrm{P}$, infected (ISH positive) pollen grains; $\mathrm{Pa}$, pollen grain aperture; $\mathrm{Phl}$, phloem tissue; and $F$, filament of the anther.
}
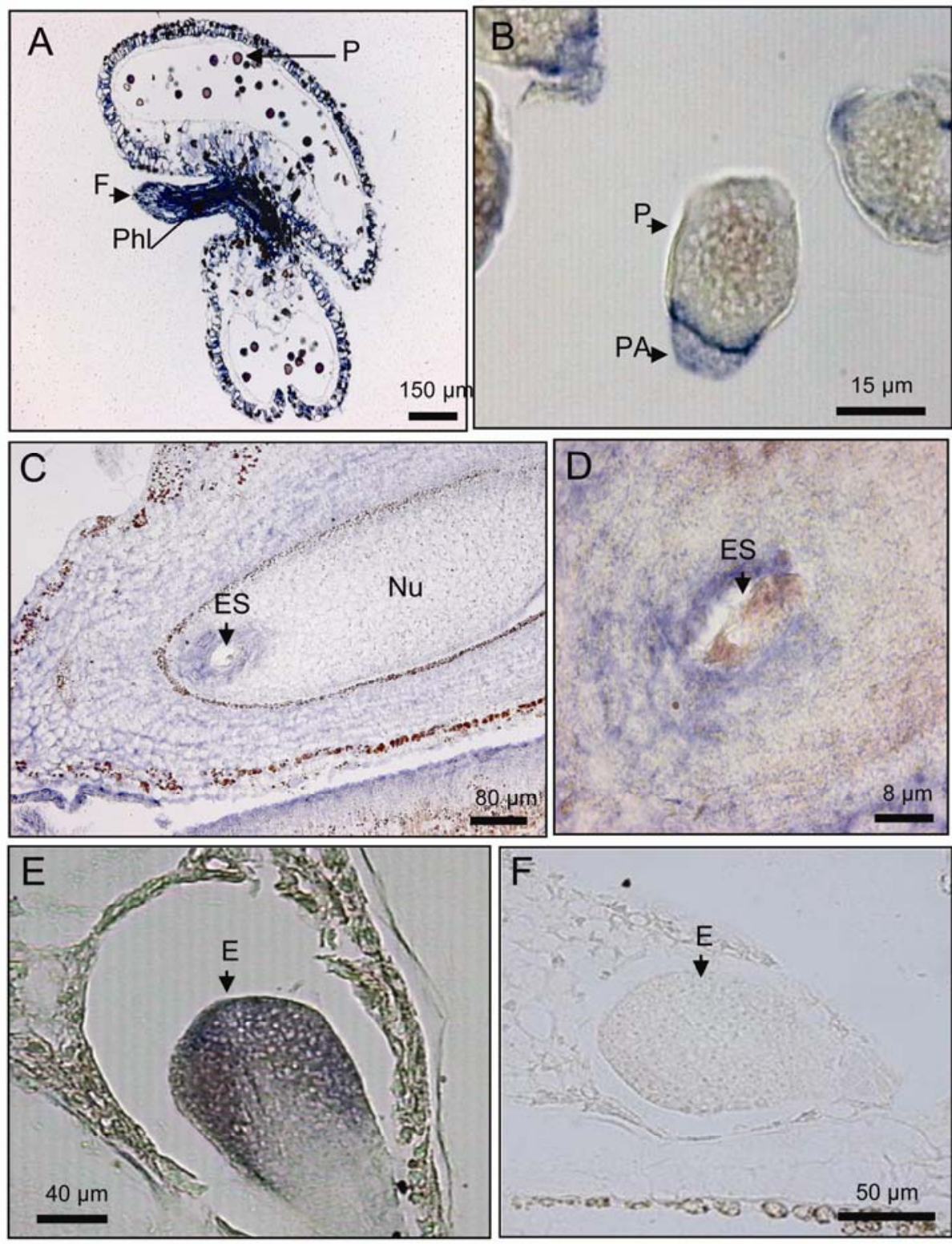
mended that growers should avoid planting the same cultivars near an infected orchard as a control strategy. Effective management also requires prompt removal and destruction of trees infected with PDV or PNRSV, but this is difficult to be accepted by the growers and practically no one does it in practice. Such a measure is recommended also for ApMV and APLPV, even though their natural transmission has not been demonstrated. In particular, APLPV has a quarantine status in some areas (i.e., EPPO region), where strict eradication measures should be taken if it occurs in the field.

There is no experience of breeding work for conventional resistance done with stone fruits against ilarviruses. A posttranscriptional gene silencing-based approach for engineering multivirus resistance in plants was developed by the fusion of 400- to 500-base pair (bp) fragments from six major Prunus fruit viruses, including APLPV, PNRSV, and PDV (98). Although immunity was not achieved, the developed construct was able to confer gene silencing-based resistance to multiple Prunus fruit viruses in plants of $N$. benthamiana. On the other hand, Raquel et al. (136) used transgenic plants of $N$. benthamiana expressing either the CP RNA or a mutated CP sequence of PDV revealing the possibility of achieving protection against this virus. However, the efficiency of the resistance against PDV of these transgenic plants is not linear, probably due to several factors such as the physiological state of the host plant and the ability of the virus to counteract the resistance, and so it needs to be improved.

\section{CONCLUSIONS AND FUTURE PERSPECTIVES}

In the last 20 years, significant progress has been made in our knowledge of the biology and molecular biology of ilarviruses infecting fruit trees. We now have a more informed picture about their diagnosis, incidence, genomic organization, and expression, and about the potential mechanisms by which they are transmitted. However, we are still far from knowing how these viruses exert their pathogenic effects in susceptible hosts. Studies of host-virus interactions are still lacking for this type of virus and only experimental hosts have been primarily used to date. For instance, in addition to PPV and Tomato ringspot virus, Dardick (47) included PNRSV in a comparative expression profiling of leaves of $N$. benthamiana systemically infected with these three fruit tree viruses. However, because PNRSV causes mild symptoms in this host, it did not induce the expression of any pathogenesis- or stress-related genes, and all of the six genes identified in this category were repressed. Obviously, this type of study would be more informative if peach/apricot arrays were used. These should be available in the near future.

Mixed infections of ilarviruses occur frequently in infected fruit trees. Although the phenotypic effects of these coinfections have long been known, their effect on either the biology of these viruses or the host responses is still a challenge for "ilarvirologist." The response of susceptible hosts to ilarvirus infection has only been recently studied. Bellés et al. (24) reported that PNRSV infection of cucumber plants induced the accumulation of gentisic acid as a signal for the activation of plant defenses. On the other hand, the same infected plants also had activated the phenylpropanoid pathway as a component of the response of cucumber to viruses producing systemic infections (25). The use of high throughput technologies would be useful to advance ilarvirushost interactions to identify key genes involved in pathogenicity functions in their respective hosts and help to design strategies for their control.

\section{ACKNOWLEDGMENTS}

We would like to apologize to those people whose relevant publications could not be cited because of space constraints. M. C. Herranz and F. Aparicio were recipients of a contract from the Juan de la Cierva and the Ramon y Cajal (RYC-2010-06169) programs of the Ministerio de Ciencia e Innovación of Spain. We are in debt to three anonymous reviewers for their valuable comments and suggestions. This work was supported by grant BIO2011-25018 from the Spanish granting agency DGICYT and the Prometeo Program GV2011/003 from the Generalitat Valenciana.

\section{LITERATURE CITED}

1. Abascal, F., Zardoya, R., and Posada, D. 2005. ProtTest: Selection of best-fit models of protein evolution. Bioinformatics 21(9):2104-2105.

2. Abou-Jawdah, Y., Sobh, H., Cordahi, N., Kawtharani, H., Nemer, G., Maxwell, D. P., and Nakhla, M. K. 2004. Immunodiagnosis of Prune dwarf virus using antiserum produced to its recombinant coat protein. J. Virol. Methods 121:31-38.

3. Alayasa, N., Al Rwahnih, M., Myrta, A., Herranz, M. C., Minafra, A., Boscia, D., and Pallás, V. 2003. Identification and characterization of an American plum line pattern virus isolate from Palestine. J. Plant Pathol. 85:3-7.

4. Al Rwahnih, M., Myrta, M., Herranz, M. C., and Pallás, V. 2004. Monitoring American plum line pattern virus in plum by ELISA and dotblot hybridisation throughout the year. J. Plant Pathol. 86:167-169.

5. Amari, K., Burgos, L., Pallás, V., and Sánchez-Pina, M. A. 2007. Prunus necrotic ringspot virus early invasion and its effects on apricot pollen grains performance. Phytopathology 97:892-899.

6. Amari, K., Burgos, L., Pallás, V., and Sánchez-Pina, M. A. 2009. Vertical transmission of Prunus necrotic ringspot virus: Hitch-hiking from gametes to seedling. J. Gen. Virol. 90:1767-1774.

7. Amari, K., Diaz-Vivancos, P., Pallás, V., Sánchez-Pina, M. A., and Hernández, J. A. 2007. Oxidative stress induction by Prunus necrotic ringspot virus inactivation infection in apricot seeds. Physiol. Plant 131:302-310.

8. Ansel-McKinney, P., and Gehrke, L. 1998. RNA determinants of a specific RNA-coat protein peptide interaction in Alfalfa mosaic virus: Conservation of homologous features in ilarvirus RNAs. J. Mol. Biol. 278:767-785.

9. Ansel-McKinney, P., Scott, S. W., Swanson, M., Ge, X., and Gehrke, L. 1996. A plant viral coat protein RNA binding consensus sequence contains a crucial arginine. EMBO J. 15:5077-5084.

10. Aparicio, F., Aparicio-Sanchis, R., Gadea, J., Sánchez-Navarro, J. A., Pallás, V., and Murguía, J. R. 2011. A plant virus movement protein regulates the Gcn2p kinase in budding yeast. PLoS ONE 6(11):e27409.

11. Aparicio, F., Myrta, A., Di Terlizzi, B., and Pallas, V. 1999. Molecular variability among isolates of Prunus necrotic ringspot virus from different Prunus spp. Phytopathology 89:991-999.

12. Aparicio, F., and Pallás, V. 2002. Molecular variability analysis of the RNA 3 of fifteen isolates of Prunus necrotic ringspot virus sheds light on the minimal requirements for the synthesis of the subgenomic RNA. Virus Genes 25:75-84.

13. Aparicio, F., Sánchez-Navarro, J. A., Olsthoorn, R. C. L., Pallás, V., and Bol, J. F. 2001. Recognition of cis-acting sequences in RNA 3 of Prunus necrotic ringspot virus by the replicase of Alfalfa mosaic virus. J. Gen. Virol. 82:947-951.

14. Aparicio, F., Sánchez-Navarro, J. A., and Pallás, V. 2006. In vitro and in vivo mapping of the Prunus necrotic ringspot virus coat protein Cterminal dimerization domain by bimolecular fluorescence complementation. J. Gen. Virol. 87:1745-1750.

15. Aparicio, F., Sánchez-Navarro, J. A., and Pallás, V. 2010. Implication of the $\mathrm{C}$ terminus of the Prunus necrotic ringspot virus movement protein in cell-to-cell transport and in its interaction with the coat protein. J. Gen. Virol. 91:1865-1870.

16. Aparicio, F., Sánchez-Pina, M. A., Sánchez-Navarro, J. A., and Pallás, V. 1999. Location of Prunus necrotic ringspot ilarvirus within pollen grains of infected nectarine trees: Evidence from RT-PCR, dot-blot and in situ hybridisation. Eur. J. Plant Pathol. 105:623-627.

17. Aparicio, F., Vilar, M., Perez-Paya, E., and Pallas, V. 2003. The coat protein of Prunus necrotic ringspot virus specifically binds to and regulates the conformation of its genomic RNA. Virology 313:213-223.

18. Aramburu, J., and Rovira, M. 1994. Effect of Apple mosaic virus (ApMV) on the growth and the yield of 'Negret' hazelnut. Acta Hortic. 386:565-568.

19. Atanasoff, D. 1935. Mosaic of stone fruits. Phytopathol. Z. 8:259-284.

20. Baer, M., Houser, F., Loesch-Fries, L. S., and Gehrke, L. 1994. Specific RNA binding by amino-terminal peptides of Alfalfa mosaic virus coat protein. EMBO J. 13:727- 735.

21. Barba, M., and Hadidi, A. 2011. DNA microarrays and other future trends in detection and typing of viruses, viroids and phytoplasmas. Pages 361372 in: Virus and Virus-Like Diseases of Pome and Stone Fruits. A. Hadidi, M. Barba, T. Candresse, and W. Jelkmann, eds. American Phyto- 
pathological Society, St. Paul, MN.

22. Barba, M., Martino, L., and Lauretti, F. 1992. Comparison of different methods to produce virus free stone fruits. Acta Hortic. 309:385-392.

23. Barba, M., Pasquini, G., and Quacquarelli, A. 1986. Role of seeds in the epidemiology of two almond viruses. Acta Hortic. 193:127-130.

24. Bellés, J. M., Garro, R., Pallás, V., Fayos, J., Rodrigo, I., and Conejero, V. 2006. Accumulation of gentisic acid as associated with systemic infections but not with the hypersensitive response in plant-pathogen interactions. Planta 223:500-511.

25. Belles, J. M., Lopez-Gresa, M. P., Fayos, J., Pallás, V., Rodrigo, I., and Conejero, V. 2008. Induction of cinnamate 4-hydroxylase and phenylpropanoids in virus-infected cucumber and melon plants. Plant Sci. 174:524-533.

26. Bjarnason, E. N., Hanger, B. C., Moran, J. R., and Cooper, J. A. 1985. Production of Prunus necrotic ringspot virus-free roses by heat treatment and tissue culture. N.Z. J. Agric. Res. 28:151-156.

27. Boari, A., Boscia, D., Di Terlizzi, B., and Savino, V. 1998. Study on seed transmission of Prune dwarf virus (PDV) in Prunus mahaleb L. Adv. Hortic. Sci. 12:89-92.

28. Bol, J. F. 2005. Replication of alfamo- and ilarviruses: Role of the coat protein. Annu. Rev. Phytopathol. 43:39-62.

29. Bouani, A., Al-Rwahnih, M., Ghanem-Sabanadzovic, N. A., Alami, I., Zemzami, M., and Myrta, A. 2004. A preliminary account of the sanitary status of stone fruit trees in Morocco. EPPO Bull. 34:399-402.

30. Boulila, M. 2009. Recombination structure and genetic relatedness among members of the family Bromoviridae based on their RNAs 1 and 2 sequence analyses. Virus Genes 38:435-444.

31. Bradford, F. C., and Joly, L. 1993. Infectious variegation in the apple. J. Agric. Res. 46:901-908.

32. Bujarski, J., Figlerowicz, M., Gallitelli, D., Roossinck, M. J., and Scott, S. W. 2012. Family Bromoviridae. Pages 965-976 in: Virus Taxonomy. Ninth Report of the International Committee on Taxonomy of Viruses. Elsevier Academic Press, San Diego, CA.

33. Çağlayan, K., Ulubas-Serce, C., Gazel, M., and Varveri, C. 2011. Prune dwarf virus. Pages 199-205 in: Virus and Virus-Like Diseases of Pome and Stone Fruits. A. Hadidi, M. Barba, T. Candresse, and W. Jelkmann, eds. American Phytopathological Society, St. Paul, MN.

34. Cambra, M., Boscia, D., Gil, M., Bertolini, E., and Olmos, A. 2011. Immunology and immunological assays applied to the detection, diagnosis and control of fruit tree viruses. Pages 303-314 in: Virus and VirusLike Diseases of Pome and Stone Fruits. A. Hadidi, M. Barba, T. Candresse, and W. Jelkmann, eds. American Phytopathological Society, St. Paul, MN.

35. Cameron, H. R., and Thompson, M. 1985. Seed transmission of Apple mosaic virus in hazelnut. Acta Hortic. 193:131.

36. Candresse, T., Kofalvi, S. A., Lanneau, M., and Dunez, J. 1998. A PCRELISA for the simultaneous detection and identification of Prunus necrotic ringspot (PNRSV) and Apple mosaic (APMV) ilarviruses. Acta Hortic. 472:219-224.

37. Cembali, T., Folwell, R. J., Wandschneider, P., Eastwell, K. C., and Howell, W. E. 2003. Economic implications of a virus prevention program in deciduous tree fruits in the US. Crop Prot. 22:1149-1156.

38. Chare, E. R., and Holmes, E. C. 2004. Selection pressures in the capsid genes of plant RNA viruses reflect mode of transmission. J. Gen. Virol. 85:3149-3157.

39. Choueiri, E., Myrta, A., Herranz, M. C., Hobeika, C., Digiaro, M., and Pallas, V. 2006. First report of American plum line pattern virus in Lebanon. J. Plant Pathol. 88:227-227.

40. Cochran, L. C., and Hutchins, L. M. 1941. A severe ringspot virus on peach. Phytopathology 31:860.

41. Codoñer, F. M., Cuevas, J. M., Sanchez-Navarro, J. A., Pallas, V., and Elena, S. F. 2005. Molecular evolution of the plant virus family Bromoviridae based on RNA3-encoded proteins. J. Mol. Evol. 61:697705.

42. Codoñer, F. M., and Elena, S. F. 2006. Evolutionary relationships among members of the Bromoviridae deduced from whole proteome analysis. Arch. Virol. 151:299-307.

43. Codoñer, F. M., Fares, M. A., and Elena, S. F. 2006. Adaptive covariation between the coat and movement proteins of Prunus necrotic ringspot virus. J. Virol. 80:5833-5840.

44. Converse, R. H., and Casper, R. 1975. A member of the apple mosaic virus group occurring in Rubus. Acta Hortic. 44:63-64.

45. Crosslin, J. M., Hammond, R. W., and Hammerschlag, F. A. 1992. Detection of Prunus necrotic ringspot virus serotypes in herbaceous and Prunus hosts with a complementary RNA probe. Plant Dis. 76:1132-1136.

46. Culver, J. N., and Padmanabhan, M. S. 2007. Virus-induced disease: Altering host physiology one interaction at a time. Annu. Rev. Phytopathol. 45:221-243.

47. Dardick, C. 2007. Comparative expression profiling of Nicotiana benthamiana leaves systemically infected with three fruit tree viruses. Mol.
Plant-Microbe Interact. 20:1004-1017.

48. Desvignes, J. C. 1999. Virus diseases of fruit trees. Centre Technique Intraprofessionnel des Fruits et Legumes, Paris, France.

49. Diekmann, M., and Putter, C. A. J. 1996. Technical guidelines for the safe movement of germplasm. Stone fruits No. 16. FAO/IPGRI, Rome.

50. Domier, L. L., Hobbs, H. A., McCoppin, N. K., Bowen, C. R., Steinlage, T., Chang, S., Wang, Y., and Hartman, G. L. 2011. Multiple loci condition seed transmission of Soybean mosaic virus (SMV) and SMV-induced seed coat mottling in soybean. Phytopathology 101:750-756.

51. Door Peeters, A. 2009. Characterisation of a potential suppressor of RNA silencing of Parietaria mottle virus (PMoV). Master thesis. Universidad Politécnica de Valencia.

52. Edgar, R. C. 2010. Quality measures for protein alignment benchmarks. Nucleic Acids Res. 38(7):2145-2153.

53. Fauquet, C. M., Mayo, M. A., Maniloff, J., Desselberger, U., and Ball, L. A. 2005. Virus Taxonomy. Classification and nomenclature of viruses. Pages 1049-1059 in: Eighth Report of the International Committee on the Taxonomy of Viruses. International Union of Microbiological Societies. Elsevier Academic Press, Amsterdam.

54. Fiore, N., Fajardo, T. V., Prodan, S., Herranz, M. C., Aparicio, F., Montealegre, J., Elena, S. F., Pallas, V., and Sanchez-Navarro, J. A. 2008. Genetic diversity of the movement and coat protein genes of South American isolates of Prunus necrotic ringspot virus. Arch. Virol. 153:909-919.

55. Foissac, X., Svanella-Dumas, L., Dulucq, M. J., Candresse, T., Gentit, P., and Clark, M. F. 2001. Polyvalent detection of fruit tree tricho, capillo and foveaviruses by nested RT-PCR using degenerated and inosine containing primers (PDO RT-PCR). Acta Hortic. 550:37-43.

56. Fonseca, F., Neto, J. D., Martins, V., and Nolasco, G. 2005. Genomic variability of Prune dwarf virus as affected by agricultural practice. Arch. Virol. 150:1607-1619.

57. Frosheiser, F. I. 1974. Alfalfa mosaic virus transmission to seed through alfalfa gametes and longevity in alfalfa seed. Phytopathology 64:102-105.

58. Fulton, R. W. 1964. Transmission of plant viruses by grafting, dodder, seed and mechanical inoculation. Pages 39-67 in: Plant Virology. M. K. Corbett and H. D. Sisler, eds. University of Florida Press, Gainesville, FL.

59. Fulton, R. W. 1982. Ilar-like characteristics of American plum line pattern virus and its serological detection in Prunus. Phytopathology 72:1345-1348.

60. Glasa, M., Betinová, E., Kúdela, O., and Subr, Z. 2002. Biological and molecular characterization of Prunus necrotic ringspot virus isolates and possible approaches to their phylogenetic typing. Ann. App. Biol. 140:279-283.

61. Gorbalenya, A. E., and Koonin, E. V. 1993. Helicase: Amino acid sequence comparisons and structure-function relationships. Curr. Opin. Struct. Biol. 3:419-429.

62. Greber, R. S., Teakle, D. S., and Mink, G. I. 1992. Thrips-facilitated transmission of prune dwarf and Prunus necrotic ringspot viruses from cherry pollen to cucumber. Plant Dis. 76:1039-1041.

63. Gumus, M., Can Paylan, I., Matic, S., Myrta, A., Sipahioglu, M. H., and Erkan, S. 2007. Occurrence and distribution of stone fruit viruses and viroids in commercial plantings of Prunus species in Western Anatolia, Turkey. J. Plant Pathol. 89:265-269.

64. Guo, D., Maiss, E., Adam, G., and Casper, R. 1995. Prunus necrotic ringspot ilarvirus: Nucleotide sequence of RNA3 and the relationship to other ilarviruses based on coat protein comparison. J. Gen. Virol. 76:1073-1079.

65. Guo, H. S., and Ding, S. W. 2002. A viral protein inhibits the long range signalling activity of the gene silencing signal. EMBO J. 21:398-407.

66. Hadidi, A., and Barba, M. 2011. Economic impact of pome and stone fruit viruses and viroids. Pages 1-8 in: Virus and Virus-Like Diseases of Pome and Stone Fruits. A. Hadidi, M. Barba, T. Candresse, and W. Jelkmann, eds. American Phytopathological Society, St. Paul, MN.

67. Hadidi, A., Olmos, A., Pasquini, G., Barba, M., Martin, R. R., and Shamloul, A. M. 2011. Polymerase chain reaction for detection of systemic plant pathogens. Pages 341-359 in: Virus and Virus-Like Diseases of Pome and Stone Fruits. A. Hadidi, M. Barba, T. Candresse, and W. Jelkmann, eds. American Phytopathological Society, St. Paul, MN.

68. Halk, E. L., Hsu, H. T., Aebig, J., and Franke, J. 1984. Production of monoclonal antibodies against three ilarviruses and Alfalfa mosaic virus and their use in serotyping. Phytopathology 74:367-372.

69. Hammond, R. W. 2003. Phylogeny of isolates of Prunus necrotic ringspot virus from the Ilarvirus ring test and identification of group-specific features. Arch. Virol. 148:1195-1210.

70. Hammond R. W. 2011. Prunus necrotic ringspot virus. Chapter 38 in: Virus and Virus-Like Diseases of Pome and Stone Fruits. A. Hadidi, M. Barba, T. Candresse and W. Jelkmann, eds. American Phytopathological Society, St. Paul, MN.

71. Hammond, R. W., and Crosslin, J. M. 1995. The complete nucleotidesequence of RNA-3 of a peach isolate of Prunus necrotic ringspot virus. Virology 208:349-353. 
72. Hammond, R. W., and Crosslin, J. M. 1998. Virulence and molecular polymorphism of Prunus necrotic ringspot virus isolates. J. Gen. Virol. 79:1815-1823.

73. Hammond, R. W., Crosslin, J. M., Pasini, R., Howell, H. E., and Mink, G. I. 1999. Differentiation of closely related but biologically distinct cherry isolates of Prunus necrotic ringspot virus by polymerase chain reaction. J. Virol. Methods 80:203-212.

74. Herranz, M. C., Al-Rwahnih, M., Sánchez-Navarro, J. A., Elena, S. F., Choueiri, E., Myrta, A., and Pallás, V. 2008. Low genetic variability in the coat and movement proteins of American plum line pattern virus isolates from different geographic origins. Arch. Virol. 153:367-373.

75. Herranz, M. C., and Pallas, V. 2004. RNA-binding properties and mapping of RNA-binding domain from the movement protein of Prunus necrotic ringspot virus. J. Gen. Virol. 85:761-768.

76. Herranz, M. C., Sánchez-Navarro, J. A., Aparicio, F., and Pallás, V. 2005. Simultaneous detection of six stone fruit viruses by non-isotopic molecular hybridization using a unique riboprobe or 'polyprobe'. J. Virol. Methods 124:49-55.

77. Herranz, M. C., Sanchez-Navarro, J. A., Sauri, A., Mingarro, I., and Pallas, V. 2005. Mutational analysis of the RNA-binding domain of the Prunus necrotic ringspot virus (PNRSV) movement protein reveals its requirement for cell-to-cell movement. Virology 339:31-41.

78. Heuss-LaRossa, K., Hammond, R., Crosslin, J. M., Hazel, C., and Hammerschlag, F. A. 1995. Monitoring of Prunus necrotic ringspot virus infection by hybridization with a cRNA probe after in vitro micrografting. J. Am. Soc. Hort. Sci. 120:928-931.

79. Hong-Wu, X., Liang-Hui, J., Simon, W. S., Robert, H. S., and Shou-Wei, D. 1998. Ilarviruses encode a Cucumovirus-like $2 \mathrm{~b}$ gene that is absent in other genera within the Bromoviridae. J. Virol. 72:6956-6959.

80. Hull, R. 2002. Matthews' Plant Virology. 4rd ed. Academic Press, New York.

81. James, D., Varga, A., Pallas, V., and Candresse, T. 2006. Strategies for simultaneous detection of multiple plant viruses. Can. J. Plant Pathol. 28:16-29.

82. Jarosova, J., and Kundu, J. K. 2010. Simultaneous detection of stone fruit tree viruses by one-step multiplex RT-PCR. Sci. Hortic. 125:68-72.

83. Jelkmann, W. 2004. Detection of virus and virus-like diseases of fruit trees. Laboratory assays, bioassays and indicators. Acta Hortic. 657:575-596.

84. Johansen, E., Edwards, M. C. and Hampton, R. O. 1994. Seed transmission of viruses: Current perspectives. Annu. Rev. Phytopathol. 32:363-386.

85. Jones, A. L., and Sutton, T. B. 1996. Prunus necrotic ringspot. Pages 9293 in: Diseases of Tree Fruits in the East. Michigan State University Publish, MI

86. Jones, A. L., and Sutton, T. B. 1996. Sour cherry yellows. Page 94 in: Diseases of Tree Fruits in the East. Michigan State University Publish, MI.

87. Jones, D. T., Taylor, W. R., and Thornton, J. M. 1992. The rapid generation of mutation data matrices from protein sequences. Comput. Appl. Biosci. 8:275-282.

88. Juarez, J., Arregui, J. M., Camarasa, E., Cambra, M., Llácer, G., Ortega, C., Ortega, V., and Navarro, L. 1998. Recovery of virus-free peach trees from selected clones by shoot-tip grafting in vitro. Acta Hortic. 235:77-83.

89. Kirkpatrick, H. C., Cheney, P. W., and Linder, R. C. 1964. Mechanical transmission of Plum line pattern virus. Plant Dis. Rep. 48:616-618.

90. Kölber, M., Nemeth, M., Krizbai, L., Szemes, M., and Kiss-Toth, E. 1998. Detectability of Prunus necrotic ringspot and Plum pox virus by RT-PCR, ELISA and indexing on woody indicators. Acta Hortic. 472:243-247.

91. Koonin, E. V. 1991. The phylogeny of RNA-dependent RNA polymerases of positive-strand RNA viruses. J. Gen. Virol. 72:2197-1106.

92. Kryczynski, S., Szyndel, M. S., Stawiszynska, A., and Piskorek, W. 1992. The rate and the way of Prunus necrotic ringspot virus spread in sour cherry orchard and in the rootstock production. Acta Hortic. 309:105-110.

93. Laimer, M. 2003. Detection and elimination of viruses and phytoplasmas from pome and stone fruit trees. Hortic. Rev. 28:187-236.

94. Lakshmi, V., Hallan, V., Ram, R., Ahmed, N., Zaidi, A., and Varma, A. 2011. Diversity of Apple mosaic virus isolates in India based on coat protein and movement protein genes. Indian J. Virol. 22:44-49.

95. Lansac, M., Detienne, G., Bernhard, R., and Dunez, J. 1980. Analysis of nine isolates of almond mosaic. Acta Phytopathol. 15:359-366.

96. Lee, G. P., Ryu, K. H., Kim, H. R., Kim, C. S., Lee, D. W., Kim, J. S., Park, M. H., Noh, Y. M., Choi, S. H., Han, D. H., and Lee, C. H. 2002. Cloning and phylogenetic characterization of coat protein genes of two isolates of Apple mosaic virus from 'Fuji' apple. Plant Pathol. J. 18:259-265.

97. Lenz, O., Petrzik, K., and Spak, J. 2008. Investigating the sensitivity of a fluorescence-based microarray for the detection of fruit-tree viruses. J. Virol. Methods 148:96-105.

98. Liu, Z., Scorza, R., Hily, J. M., Scott, S. W. and James, D. 2007. Engineering resistance to multiple Prunus fruit viruses through expression of chimeric hairpins. J. Am. Soc. Hort. Sci. 132:407-414.

99. Maliogka, V. I., Dovas, C. I., and Katis, N. I. 2007. Demarcation of ilarviruses based on the phylogeny of RNA2-encoded RdRp and generic ramped annealing RT-PCR. Arch. Virol. 152:1687-1698.

100. Manganaris, G. A., Economou, A. S., Boubourakas, I. N., and Katis, N. I. 2003. Elimination of PPV and PNRSV through thermotherapy and meristem-tip culture. Plant Cell Rep. 22:195-200.

101. Martelli, G. P., and Savino, V. 1997. Infectious diseases of almond with special reference to the Mediterranean area. EPPO Bull. 27:525-534.

102. Martínez-Gil, L., Sánchez-Navarro, J. A., Cruz, A., Pallás, V., Pérez-Gil, J., and Mingarro, I. 2009. Plant virus cell-to-cell movement is not dependent on the transmembrane disposition of its movement protein. J. Virol. 83:5535-5543.

103. Más, P., and Pallás, V. 1995. Non-isotopic tissue-printing hybridization: A new technique to study long-distance plant virus movement. J. Virol. Methods 52:317-326.

104. Massart, S., Brostaux, Y., Barbarossa, L., Cesar, V., Cieslinska, M., Dutrecq, O., Fonseca, F., Guillem, R., Lavina, A., Olmos, A., Steyer, S., Wetzel, T., Kummert, J., and Jijakli, M. H. 2008. Inter-laboratory evaluation of a duplex RT-PCR method using crude extracts for the simultaneous detection of Prune dwarf virus and Prunus necrotic ringspot virus. Eur. J. Plant Pathol.122:539-547.

105. Matic, S., Al-Rwahnih, M., Myrta, A., and Duric, G. 2008. Viruses of stone fruits in Bosnia and Herzegovina. Acta Hortic. 781:71-74.

106. Matic, A., Sánchez-Navarro, J.A., Mandic, B., Myrta, A., and Pallás, V. 2008. Tracking three ilarviruses in stone fruit trees throughout the year by ELISA and tissue-printing hybridization. J. Plant Pathol. 90:137-141.

107. Maule, A. J., and Wang, D. 1996. Seed transmission of plant viruses: A lesson in biological complexity. Trends Microbiol. 4:153-158.

108. Melcher, U. 2000. The " $30 \mathrm{~K}$ " superfamily of viral movement proteins. J. Gen. Virol. 81:257-266.

109. Menzel, W., Jelkmann, W., and Maiss, E. 2002. Detection of four apple viruses by multiplex RT-PCR assays with coamplification of plant mRNA as internal control. J. Virol. Methods 99:81-92.

110. Mink, G. I. 1992. Ilarvirus vectors. Adv. Dis. Vec. Res. 9:261-281.

111. Mink, G. I. 1993. Pollen- and seed-transmitted viruses and viroids. Annu. Rev. Phytopathol. 31:375-402.

112. Mink, G. I., Howell, W. E., Cole, A., and Regev, S. 1987. Three serotypes of Prunus necrotic ringspot virus isolated from rugose mosaicdiseased sweet cherry trees in Washington. Plant Dis 71:91-93.

113. Mushegian, A. R., and Koonin, E. V. 1993. Cell-to-cell movement of plant-viruses-insights from amino-acid-sequence comparisons of movement proteins and from analogies with cellular-transport systems. Arch. Virol. 133:239-257.

114. Myrta, A., Abbadi, H., Herranz, M. C., Al-Rwahnih, M., Di-Terlizzi, B., Minafra, A., and Pallás, V. 2002. First report of American plum line pattern virus (APLPV) in Albania, Italy and Tunisia. J. Plant Pathol. 84:188.

115. Myrta, A., Di-Terlizzi B., Savino, V., and Martelli, G. P. 2003. Virus diseases affecting the Mediterranean stone fruit industry: A decade of surveys. Pages 15-23. Option Méditerranéennes, Sér. B/n ${ }^{\circ} 4$.

116. Myrta, A., Herranz, M. C., Choueiri, E., and Pallás, V. 2011. American Plum line pattern virus. Chapter 17, pages 181-183 in: Virus and VirusLike Diseases of Pome and Stone Fruits. A. Hadidi, M. Barba, T. Candresse, and W. Jelkmann, eds. American Phytopathological Society, St. Paul, MN.

117. Myrta, A., Sanchez-Navarro, J., Potere, O., Boscia, D., and Pallás, V. 2009. First report of American plum line pattern virus in flowering cherry in Italy. Atti del XV Congresso nazionale della societa italiana di Patologia Vegetale (SIPaV), Locorotondo.

118. Nagano, H., Mise, K., Furusawa, I., and Okuno, T. 2001. Conversion in the requirement of coat protein in cell-to-cell movement mediated by the Cucumber mosaic virus movement protein. J. Virol. 75:8045-8053.

119. Navarro, L. 1998. Application of shoot-tip grafting in vitro to woody species. Acta Hortic. 227:43-55.

120. Nemeth, M. 1986. Virus, Mycoplasma and Rickettsia Diseases of fruit trees. Martinus Nijhoff Publishers, The Netherlands and Akademini Kiado, Hungary.

121. Nicolaisen, M. 2011. An oligonucleotide-based microarray for detection of plant RNA viruses. J. Virol. Methods 173:137-143.

122. Nyland, G., Gilmer, R. M., and Moore, J. D. 1976. "Prunus" ringspot group. Pages 104-132 in: Virus Diseases and Non-Infectious Disorders of Stone Fruits in North America. R. M. Gilmer, J. D. Moore, G. Nyland, M. F. Welsh, and T. S. Pine, eds. Agriculture Handbook No. 437, USDA, Washington, DC.

123. Oliver, J. E., Freer, J., Andersen, R. L., Cox, K. D., Robinson, T. L., and Fuchs, M. 2009. Genetic diversity of Prunus necrotic ringspot virus isolates within a cherry orchard in New York. Plant Dis. 93:599-606.

124. Olsthoorn, R. C. L., Mertens, S., Brederode, Th. B., and Bol, J. F. 1999. A conformational switch at the $3^{\prime}$ end of a plant virus RNA regulates viral replication. EMBO J. 18:4856-4864.

125. Pallás, V., Faggioli, F., Aparico, F., and Sanchez-Navarro, J. A. 2011. Molecular hybridization techniques for detecting and studying fruit tree 
viruses and viroids. Pages 335-342 in: Virus and Virus-Like Diseases of Pome and Stone Fruits. A. Hadidi, M. Barba, T. Candresse, and W. Jelkmann, eds. American Phytopathological Society, St. Paul, MN.

126. Pallás, V., and Garcia, J. A. 2011. How do plant viruses induce disease? Interactions and interference with host components. J. Gen. Virol. 92:2691-2705.

127. Pallás, V., Más, P., and Sánchez-Navarro, J. A. 1998. Detection of plant RNA viruses by nonisotopic dot-blot hybridization. Methods Mol. Biol. 81:461-468.

128. Pallás, V., Sanchez-Navarro, J. A., and Diez, J. 1999. In vitro evidence for RNA binding properties of the coat protein of Prunus necrotic ringspot ilarvirus and their comparison to related and unrelated viruses. Arch. Virol. 144:797-803.

129. Pasquini, G., and Barba, M. 1991. Production and application of monoclonal antibodies against Apple mosaic virus. Petria 1:31-36.

130. Paulsen, A. Q., and Fulton, R. W. 1968. Hosts and properties of a plum line pattern virus. Phytopathology 58:766-772.

131. Paunovic, S., Pasquini, G., and Barba, M. 2011. Apple mosaic virus. Chapter 18, pages 91-95 in: Virus and Virus-Like Diseases of Pome and Stone Fruits. A. Hadidi, M. Barba, T. Candresse, and W. Jelkmann, eds. American Phytopathological Society, St. Paul, MN.

132. Peiró, A., Pallás, V., and Sánchez-Navarro, J. A. 2012. Simultaneous detection of eight viruses and two viroids affecting stone fruit trees by using a unique polyprobe. Eur. J. Plant Pathol. 132:469-475.

133. Petrzik, K., and Lenz, O. 2002. Remarkable variability of Apple mosaic virus capsid protein gene after nucleotide position 141. Arch. Virol. 147:1275-1285

134. Posnette, A. F., and Ellenberger, C. E. 1957. The line-pattern virus disease of plums. Ann. App. Biol. 45:74-80.

135. Rampitsch, C., and Eastwell, K. C. 1997. The complete nucleotide sequence of prune dwarf ilarvirus RNA-1. Arch. Virol. 142:1911-1918.

136. Raquel, H., Lourenço, T., Moita, C., and Oliveira, M. M. 2008. Expression of prune dwarf Ilarvirus coat protein sequences in Nicotiana benthamiana plants interferes with PDV systemic proliferation. Plant Biotech. Rep. 2:75-85.

137. Reusken, C. B. E. M., and Bol, J. F. 1996. Structural elements of the $3^{\prime}-$ terminal coat protein binding site in alfalfa mosaic virus RNAs. Nucleic Acids Res. 24:2660-2665.

138. Rosner, A., Maslenin, L., and Spiegel, S. 1998. Differentiation among isolates of Prunus necrotic ringspot virus by transcript conformation polymorphism. J. Virol. Methods 74:109-115.

139. Rouag, N., Guechi, A., Matić, S., and Myrta, A. 2008. Viruses of stone fruits in Algeria. J. Plant Pathol. 90:391-393.

140. Rozanov, M., Koonin, E. V., and Gorbalenya, A.E. 1992. Conservation of the putative methyltransferase domain: a hallmark of the 'Sindbis-like' supergroup of positive-strand RNA viruses. J. Gen. Virol. 73:2129-2134.

141. Saade, M., Aparicio, F., Sánchez-Navarro, J. A., Herranz, M. C., Myrta, A., Di-Terlizzi, B., and Pállas, V. 2000. Simultaneous detection of the three ilarviruses affecting stone fruits by non-isotopic molecular hybridization and multiplex RT-PCR. Phytopathology 90:1330-1336.

142. Sánchez-Navarro, J. A., Aparicio, F., Herranz, M. C., and Pallás, V. 2005. Simultaneous detection and identification of eight stone fruit viruses by one step RT-PCR. Eur. J. Plant Pathol. 111:77-84.

143. Sánchez-Navarro, J. A., Aparicio, F., Rowhani, A., and Pallás, V. 1998. Comparative analysis of ELISA, nonradioactive molecular hybridisation and PCR for the detection of Prunus necrotic ringspot virus in herbaceous and Prunus hosts. Plant Pathol. 47:780-786.

144. Sánchez-Navarro, J. A., and Bol, J. F. 2001. Role of the Alfalfa mosaic virus movement protein and coat protein in virus transport. Mol. PlantMicrobe Interact. 14:1051-1062.

145. Sánchez-Navarro, J. A., Herranz, M. C., and Pallás, V. 2006. Cell-to-cell movement of Alfalfa mosaic virus can be mediated by the movement proteins of Ilar-, bromo-, cucumo-, tobamo- and comoviruses, and does not require virion formation. Virology 346:66-73.

146. Sánchez-Navarro, J. A., and Pallás, V. 1997. Evolutionary relationships in the ilarviruses: Nucleotide sequence of Prunus necrotic ringspot virus RNA 3. Arch. Virol. 142:749-763.

147. Sánchez-Navarro, J. A., Reusken, C. B. E. M., Bol, J. F., and Pallás, V. 1997. Replication of Alfalfa mosaic virus RNA 3 with movement and coat protein genes replaced by corresponding genes of Prunus necrotic ringspot ilarvirus. J. Gen. Virol. 78:3171-3176.

148. Saunier, R. 1972. Incidence dù virus du type ringspot sur la comportement de deux cultivars du pécher. Pomol. Fr. 14:175-185.

149. Scott, S. W., Bowman-Vance, V., and Bachman, E. J. 1992. The use of nucleic acid probes for the detection of Prunus necrotic ringspot virus and Prune dwarf virus. Acta Hortic. 309:79-83.

150. Scott, S. W., and Zimmerman, M. T. 2001. American plum line pattern virus is a distinct ilarvirus. Acta Hortic. 505:221-225.

151. Scott, S. W., Zimmerman, M. T., and Ge, X. 2003. Viruses in subgroup 2 of the genus Ilarvirus share both serological relationships and characteristics at the molecular level. Arch. Virol. 148:2063-2075.

152. Scott, S. W., Zimmerman, M. T., Ge, X., and MacKenzie, D. J. 1998. The coat proteins and putative movement proteins of isolates of Prunus necrotic ringspot virus from different host species and geographic origins are extensively conserved. Eur. J. Plant Pathol. 104:155-161.

153. Shiel, P. J., Alrefai, R. H., Domier, L. L., Korban, S. S., and Berger, P. H. 1995. The complete nucleotide sequence of Apple mosaic virus RNA-3. Arch. Virol. 140:1247-1256.

154. Shiel, P. J., and Berger, P. H. 2000. The complete nucleotide sequence of Apple mosaic virus (ApMV) RNA 1 and RNA 2: ApMV is more closely related to Alfalfa mosaic virus than to other ilarviruses. J. Gen. Virol. 81:273-278.

155. Silva, C., Tereso, S., Nolasco, G., and Oliveira, M. M. 2003. Cellular location of Prune dwarf virus in almond sections by in situ reverse transcription-polymerase chain reaction. Phytopathology 93:278-285.

156. Spiegel, S., Holland, D., Tam, Y., Bar-Yaakov, I., Maslenin, L., and Rosner, A. 2004. Prunus necrotic ringspot virus isolates in stone fruit germplasm accessions and cultivars in Israel. Ann. App. Biol. 144:229-236.

157. Takeda, A., Masanori, K., Okuno, T., and Mise, K. 2004. The C terminus of the movement protein of Brome mosaic virus controls the requirement for coat protein in cell-to-cell movement and plays a role in longdistance movement. J Gen. Virol. 85:1751-1761.

158. Tamura, K., Peterson, D., Peterson, N., Stecher, G., Nei, M., and Kumar, S. 2011. MEGA5: Molecular evolutionary genetics analysis using maximum likelihood, evolutionary distance, and maximum parsimony Meth. Mol. Biol. Evol. 28:2731-2739.

159. Thomas, H. E., and Hildebrand, E. M. 1936. A virus disease of prune. Phytopathology 26:1145-1148

160. Tzanetakis, I. E., and Martin, R. R. 2005. New features in the genus Ilarvirus revealed by the nucleotide sequence of Fragaria chiloensis latent virus. Virus Res. 112:32-37.

161. Ulubas-Serçe, Ç., Ertunç, F., and ÖZtürk, A. 2009. Identification and genomic variability of Prune dwarf virus variants infecting stone fruit in Turkey. J. Phytopathol. 157:298-305.

162. Untiveros, M., Perez-Egusquiza, Z., and Clover, G. 2010. PCR assays for the detection of members of the genus ilarvirus and family Bromoviridae. J. Virol. Methods 165:97-104.

163. Uyemoto, J. K., Bulluck, L. R., III, Pethybridge, S., McCorkell, B., and Asai, W. K. 2003. Horizontal spread of ilarviruses in young trees of several peach cultivars. Plant Dis. 87:75-77.

164. Uyemoto, J. K., Luhn, C. F., Asai, W. K., Beede, R., Beutel, J. A., and Fenton, R. 1989. Incidence of ilarviruses in young peach trees in California. Plant Dis. 73:217-220.

165. Uyemoto, J. K., and Scott, S. W. 1992. Important diseases of Prunus caused by viruses and other graft-transmissible pathogens in California and South Carolina. Plant Dis. 76:5-11.

166. Valleau, W. D. 1932. A virus disease of plum and peach. Kentucky Agric. Exp. Stn. Res. Bull. 327:89-103.

167. Van-Regenmortel, M. H. V., Fauquet, C. M., Bishop, D. H. L., Carstens, E. B., Estes, M. K., Lemon, S. M., Maniloff, J., Mayo, M. A., McGeoch, D. J., Pringle, C. R., and Wickner, R. B. 2000. Virus Taxonomy. Seventh Report of the International Committee on Taxonomy of Viruses. Academic Press, San Diego.

168. Vaskova, D., Petrzik, K., and Karesova, R. 2000. Variability and molecular typing of the woody-tree infecting Prunus necrotic ringspot ilarvirus. Arch. Virol. 145:699-709.

169. Vaskova, D., Petrzik, K., and Spak, J. 2000. Molecular variability of the capsid protein of the Prune dwarf virus. Eur. J. Plant Pathol. 106:573-580.

170. Vértesy, J. 1976. Embryological studies of Ilarvirus infected cherry seeds. Acta Hortic. 67:245-248.

171. Wang, X., Lee, W. M., Watanabe, T., Schwartx, M., Janda, M., and Ahlquist, P. 2005. Brome mosaic virus 1a nucleoside triphosphatase/ helicase domain plays crucial roles in recruiting RNA replication templates. J. Virol. 79:13747-13758.

172. Wells, J. M., and Kirkpatrick, H. C. 1986. Symptomatology and incidence of Prunus necrotic ringspot virus in peach orchards in Georgia. Plant Dis. 70:444-447.

173. Youssef, S. A., Shalaby, A. A., Mazyad, H. M., and Hadidi, A. 2002. Detection and identification of Prune dwarf virus and Plum pox virus by standard and multiplex RT-PCR probe capture hybridization (RT-PCRELISA). J. Plant Pathol. 84:113-119.

174. Yusibov, V., and Loesch-Fries, L. S. 1998. Functional significance of three basic N-terminal amino acids of Alfalfa mosaic virus coat protein. Virology 242:1-5.

175. Zhang, Y., Yin, J., Li, G., Li, M., Huang, X., Chen, H., Zhao, W., and Zhu, S. 2010. Oligonucleotide microarray with a minimal number of probes for the detection and identification of thirteen genera of plant viruses. J. Virol. Methods 167:53-60. 